Original Research Paper

\title{
Items and Generalizations: Evidence from Decir within the Family of Subjective-Transitive Constructions in Spanish
}

\author{
Gonzálvez-García, Francisco \\ Department of Philology, University of Almeria, Almeria, Spain
}

Article history

Received: 10-07-2015

Revised: 14-07-2015

Accepted: 14-07-2015

Email: fgonza@ual.es

\begin{abstract}
This paper explores the existence of a continuum between regular, productive, conventional configurations and fixed, idiosyncratic and novel configurations within the full gamut of instances of secondary predication with decir ('say') and verba dicendi in present-day Spanish. Drawing on Cognitive Construction Grammar, it is argued that instances of the secondary predication with these verbs can be aptly regarded as forming part of the family of subjective-transitive constructions. Specifically, schematic configurations involving decir and other verba dicendi are shown to be instances of the denominative subjective-transitive construction. Configurations of this kind interact with partially filled in instances of secondary predication involving coercion via a reflexive pronoun in the postverbal NP slot as well as coercion in combination with an imperative form. This continuum is even more clearly observable in the case of configurations involving the reflex passive clitic se, giving rise to a threepoint cline between (i) non-gramaticalized (compositional) configurations with an active counterpart, (ii) non-grammaticalized constructions without an active counterpart and (iii) grammaticalized (non-compositional) configurations without an active counterpart. At a higher level of delicacy, it is shown that lo que se dice XPCOMP construction, understood as the result of incipient grammaticalization, may function as a focusing/emphasizer subjunct or as a summative conjunct in present-day Spanish. One of the broad-scale generalizations emerging from this study is that the XPCOMP must lend itself to a subjective, evaluative construal on the part of the subject/speaker. All the instances of the subjective-transitive construction surveyed here impose this restriction on the XPCOMP. However, the lo que se dice XPCOMP construction functioning as a emphasizer/focusing subjunct also allows a more disparate range of non-evaluative XPCOMPs. A default inheritance system of the type invoked in Cognitive Construction Grammar is shown to capture the commonalities as well as the idiosyncratic particulars of this family of constructions and can thus be informally used to optimize the input for the instruction of grammar in the advanced Spanish L2 class.
\end{abstract}

Keywords: Subjective-Transitive Construction, Coercion, Reflexive, Imperative, Reflex Passive, Grammaticalization, Subjunct, Conjunct

\section{Introduction}

From its inception in the late 80's (Lakoff, 1987; Fillmore et al., 1988), Construction Grammar (henceforth $\mathrm{CxG}$ ) vindicates the centrality of constructions as free-standing theoretical entities with their own inherent meaning and/or function. This stance is diametrically different from the Chomskyan conception of constructions as mere taxonomic artefacts which may prove useful in linguistic description but which are nonetheless devoid of any theoretical status and explanatory power (Chomsky, 1995: 170). Thus, in stark contrast to Chomskyan linguistics, $\mathrm{CxG}$ concentrates on the rehabilitation of the notion of construction as a key unit in linguistic theory, central to a comprehensive description and explanation of the 
knowledge that language users have and the different uses they put language to. In this connection, it is particularly instructive to consider the following quote from Kay and Fillmore (1999: 1):

To adopt a constructional approach is to undertake a commitment in principle to account for the entirety of each language. This means that the relatively general patterns of the language, such as the one licensing the ordering of a finite auxiliary verb before its subject in English, often known as SAI and the highly idiomatic patterns, like kick the bucket, stand on an equal footing as data for which the grammar must account. An explicit grammar that covers the full range of constructions must represent all constructions, of whatever degree of generality or idiomaticity, in a common notation and must provide an explicit account of how each sentence of a language is licensed by a subset of the leaves of the inheritance hierarchy of constructions which constitutes the grammar of that language. (Kay and Fillmore, 1999: 1, emphasis in original)

Thus, constructionist grammarians assert that there is a smooth interaction between the relatively general, regular, productive patterns of a language and the highly idiomatic, idiosyncratic and unproductive ones. In addition, construction grammarians are committed to providing explicit, explanatory accounts of how constructions can (or cannot) be combined to produce specific instances (or constructs).

With the above observations in mind, the present paper sets out to address the following two research questions: First, what is the picture that emerges when one takes a bottom-up, usage-based analysis of instances of secondary predication in Spanish decir ('say') and verba dicendi in present-day Spanish, as in (1)-(5)?

(1) Me dicen tonto por fumar marihuana, y le dicen inteligente al creador de la bomba atómica (Bob Marley) http://frasescools.com/193128/?ref=m

'They call me a fool because I smoke pod and they call the creator of the atomic bomb intelligent'

(2) (...) [D]ame pan y dime tonto (...) (CREA, Oral, Vehículo público, conversación entre pasajeros, Madrid-Barajas, 30/06/91)

'Give me bread and call me silly'

(3) (En una reciente entrevista) Salma Hayek se dice amante de los perros

'In a recent interview, Salma Hayek declares herself fond of dogs'
(El Pais, 02/02/2004)

(4) Mr John Spencer no era lo que se dice un hombre intachable

(CREA Corpus, 1980, Anónimo, Los tripulantes de ovnis)

'Mr John Spencer was not what you may call an irreproachable man'

(5) Lo que se dice un ídolo

http://www.books.google.es/books?isbn=9506653410

'Definitely an idol!'

Second, how can a constructionist account provide a principled, explicit account of the interaction between regular, productive, conventional configurations and fixed, idiosyncratic and novel configurations within secondary predication in the constructicon (in contrast to alternative proposals that rely on transformations, derivations, alternations, etc.)?

Instances of the type illustrated in (1)-(5) are argued to form part of the family of subjective-transitive constructions in Spanish. Moreover, it will be shown that Cognitive Construction Grammar (henceforth CCG) can adequately capture the commonalities and the itemspecific properties of higher and lower-level configurations of the subjective-transitive construction through a (default) inheritance system, while providing an explicit account of their most distinctive semanticopragmatic and discourse-functional hallmarks.

The structure of this paper is as follows: First, I provide an overview of the central assumptions shared by constructionist approaches in general and CCG (Goldberg, 2006) in particular, which serves as the general background against which the findings in the present case study should be understood. Next, I outline the basics of the (high-level) Spanish subjectivetransitive construction and two of its senses, the evaluative subjective-transitive construction (with verba cogitandi) and the denominative subjective-transitive construction (with decir 'say' and other verba cogitandi). This section also takes a look at three types of lower-level configurations of this construction, involving a reflexive pronoun in the postverbal NP slot (or reflexive subjective-transitive constructions), an imperative verb form (or imperative subjective-transitive constructions) and a reflex passive clitic se (or impersonal subjective-transitive constructions). Then I examine in some detail the most salient properties of the semi-fixed lo que se dice XPCOMP construction, which, as a result of an incipient process of grammaticalization, may function as a focusing/emphasizer subjunct and as a summative conjunct. Finally, I address only briefly some points of convergence between construction grammarians, advocates of a wide phraseological view (Granger, 2011 and references therein) and practitioners 
of Phraseodidactics (González Rey, 2012) and offers some pointers for further future research.

\section{An Overview of (Cognitive) Construction Grammar}

For current purposes, the central assumptions shared by most versions of $\mathrm{CxG}$ can be summarized, according to Goldberg (2013: 15-16), as follows (see Butler and Gonzálvez-García, 2014 and references therein for further discussion):

Grammatical constructions are recognized to be key free-standing theoretical entities with explanatory power, in contrast to the mere taxonomic status assigned to these in mainstream generative grammar. In the constructionist literature, two definitions of construction can be found. The original definition of the term construction runs as follows: ${ }^{1}$

$\mathrm{C}$ is a CONSTRUCTION iff def $\mathrm{n}_{\mathrm{n}}$ is a formfunction pair, such that some aspect of the form or some aspect of the function is not strictly predictable from C's component parts. (Goldberg, 1998: 25, emphasis added to the original)

This definition of construction revolves around the criterion of idiosyncrasy or non-predictability as the sine qua non condition for construction status. Thus, consider (6):

(6) Pat faxed Bill the letter (Example taken from Goldberg, 1998: 206)

A construct like the one in (6) implies in presentday English that Bill actually received the letter by fax. However, according to Goldberg, the semantic specification of successful transfer cannot be attributed to the lexical meaning of the construct's components. In other words, the overall interpretation of successful transfer comes from the ditransitive construction, the meaning of which is X CAUSES Y TO RECEIVE $Z$, rather than from the meaning of the lexical items involved. This is why (6) qualifies as an instance of the ditransitive construction according to the original definition of the term, because its overall interpretation is non-compositional, that is, not strictly predictable from its component parts or from other constructions.

\footnotetext{
${ }^{1}$ For further details on the treatment of constructions in the presentday functional-cognitive scenario in general and constructionist approaches in particular, the interested reader is referred to Schönefeld (2006), Gonzálvez-García and Butler (2006), Mairal Usón and Gonzálvez-García (2010), as well as Butler and Gonzálvez-García (2014), inter alios.
}

However, the original idiosyncrasy (i.e., nonpredictability) requirement in the original formulation of the constructions has been recently downgraded, in concert with other cognitively-oriented usage based models such as CCG and Radical Construction Grammar (see further Goldberg, 2006: 224 for discussion). On this view, the extended, usage-based definition of a construction can be established in the following terms:
Any linguistic pattern is recognized as a construction as long as some aspect of its form or function is not strictly predictable from its component parts of from other constructions recognized to exist. In addition, patterns are stored as constructions even if they are fully predictable as long as they occur with sufficient frequency (see Ch. 3 for discussion). (Goldberg, 2006: 5, see also Langacker, 2005: 139-143 for a similar view)

An important corollary deriving from this usagebased definition is that stored (typically highly frequent) regularities between form and meaning are considered constructions even if they are fully compositional (emphasis in original) (see Goldberg, 2006: 214-215). Thus, consider (7):

\section{(7) I love you}

The construct in (7) illustrates the case of a fully transparent, compositional instance of the transitive construction. However, given the fact that it is highly frequent and highly entrenched, it qualifies as a construction on its own according to the expanded, usage-based definition of a construction. ${ }^{2}$ The question then arises as to how to justify this expansion of the definition of the notion of construction. In this connection, it is important to bear in mind Langacker's observation that:

lower-level schemas, expressing regularities of only limited scope, may on balance be more essential to language structure than high-level schemas representing the broadest generalizations. (Langacker, 2000: 3, emphasis added to the original)

Thus lower-level configurations which may involve specific items, such as idioms (e.g., going great guns, jog X's memory), are considered just as important as the

\footnotetext{
${ }^{2}$ It should be emphasized that, within Sign-Based Construction Grammar (Boas and Sag, 2012), construction grammarians such as Paul Kay do not accept this usage-based expansion of the notion of construction and rely on the original definition of the term, based on the idiosyncrasy requirement (see Kay, 2013).
} 
more abstract configurations (e.g., the ditransitive construction, Pat faxed Bill the letter).

Another compelling argument in favour of this expansion of the notion of construction stems from the following observation made by Goldberg:

[...] facts about the actual usage of linguistic expressions such as frequencies and individual patterns are recorded alongside more traditional linguistic generalizations. (Goldberg, 2006: 45)

As things stand, this expanded, usage-based definition of a construction seems particularly wellsuited to capture both broad generalizations and more limited or item-specific patterns (see further Bybee, 2010; 2013). Therefore, grammar can be best viewed as a massive network of interrelated constructions of varying degrees of generality/specificity and morphosyntactic complexity (from words to idioms to more abstract patterns such as argument structure constructions, topicalization and passive, etc) or, alternatively, a constructicon. In the words of Goldberg (2006: 18), "it's constructions all the way down". A representative sampling of the full gamut of constructions in English (and their Spanish counterparts) is illustrated in Table 1.

As can be seen in Table 1, constructions exhibit varying degrees of morphosyntactic complexity, ranging from simpler units such as the morpheme to complex constructions such as the conditional-comparative construction. In addition, constructions can feature varying degrees of generality or, conversely, of specificity. Thus, for instance, the passive construction and the resultative construction display a considerable degree of abstraction, which contrasts with the fairly specific nature of e.g., morphemes. Finally, constructions can also display different degrees of fixation. These range all the way from fully or partially filled in idioms (which allow little or no variation at all) to constructions with a high degree of abstraction, such as the passive or the resultative (which admit a considerable degree of variation). The foundational assumption underlying the inventory of constructions exemplified in Table 1 is that grammar and the lexicon, far from being two separate or independent modules (as claimed in e.g., Chomskyan linguistics), form a continuum with a soft dividing line (Croft and Cruse, 2004: 255).

Key to understanding the interaction(s) between grammar and the lexicon in $\mathrm{CxG}$ is the notion of coercion. This notion - originally due to Pustejovsky (1991) - is invoked in both $\mathrm{CxG}$ and Cognitive Grammar to handle a number of exceptional cases in which lexical items are combined with elements, whether via morphology or syntax, that they do not license semantically (Michaelis, 2003: 261; see also
Taylor, 2003: 589 for a similar definition). Specifically, coercion is argued to provide a most compelling piece of evidence for a constructionist account. This is so mainly because coercion demonstrates that syntactic (or, alternatively, constructional) meaning wins over lexical meaning (Michaelis, 2003; 2004; 2011), as shown crucially by the fact that its interpretive implications, like conventional implicatures, can neither be detached nor suspended (Michaelis, 2003: 262): ${ }^{3}$

(8) When a visitor passes through the village, young lamas stop picking up trash to mug for the camera. A gruff 'police monk' barks them to work (Newsweek 10/13/97)

(Example taken from Michaelis, 2003: 261, emphasis in original)

Example (8) involves argument structure rather than single lexical items. The important thing here is that the metaphorical caused-motion interpretation of the sentence (i.e., "the dog causes them to go to work by barking") is most parsimoniously attributed to the construction as a freestanding entity rather than to the lexical semantics of the verb bark, which is a verb of emission of sound. Thus, coercion can be understood as the resolution of a conflict between constructional and lexical denotata (Michaelis, 2003: 264; 2004), as per the Override Principle, which goes as follows: "If a lexical item is semantically incompatible with its syntactic context, the meaning of the lexical item conforms to the meaning of the structure in which it is embedded" (Michaelis, 2003: 268).

Cognitively-influenced versions of $\mathrm{CxG}$ fully subscribe to the usage-based model. The term "usagebased" was coined by Langacker (1987: 494) to describe a model in which use of the linguistic system and also knowledge of the complete set of linguistic conventions involved in this use, are regarded as important. To quote Langacker (1987: 494):

Substantial importance is given to the actual
use of the linguistic system and a speaker's
knowledge of this use; the grammar is held
responsible for a speaker's knowledge of the
full range of linguistic conventions, regardless
of whether these conventions can be
subsumed under more general statements.
(Langacker, 1987: 494)

${ }^{3}$ In this connection, it should be noted that Ziegeler $(2007 ; 2010)$ argues that the notion of coercion, as employed in constructionist circles, is superfluous, as it can be explained on the basis of metaphor and/or metonymy alone. The interested reader is referred to Gonzálvez-García (2011) for a different view that shows coercion is compatible with a metaphor/metonymy account, as advocated in e.g. the Lexical Constructional Model (Ruiz de Mendoza Ibáñez and Mairal Usón, 2008) 
Table 1.Examples of English constructions and their Spanish counterparts, varying in size and complexity (based on Goldberg, 2006: 5)

\begin{tabular}{|c|c|c|}
\hline Morpheme & anti-, pre-, -ing & $\begin{array}{l}\text { anti-N (e.g., antinuclear 'antinuclear'), } \\
\text { pre-N (e.g., prepedido, 'pre-sell') }\end{array}$ \\
\hline Word & avocado, anaconda & idiosincrasia ('idiosyncrasy'), democracia ('democracy') \\
\hline Complex word & daredevil, shoo-in & pagafantas ('friend zone'), caradura ('cheeky') \\
\hline Idiom (filled) & going great guns & $\begin{array}{l}\text { ponerse el mundo por montera ('to swing the world by its tail'), } \\
\text { prometérselas muy felices ('to have high hopes') }\end{array}$ \\
\hline Idiom (partially filled) & jog $<$ someone's $>$ memory & $\begin{array}{l}\text { ¿Por qué no intentarlo? 'Why not try it?', tener (a alguien) en } \\
\text { gran estima 'to hold (somebody) in esteem') }\end{array}$ \\
\hline Covariational Conditional & $\begin{array}{l}\text { The Xer the Yer (e.g. } \\
\text { The more you think about it, } \\
\text { the less you understand) }\end{array}$ & $\begin{array}{l}\text { Cuanto X, expresión comparativa } \mathrm{Y} \\
\text { 'Cuanto X, comparative expression Y' } \\
\text { (e.g., Cuanto más lo pienso, más dudas tengo 'The more I } \\
\text { think about it, the more doubtful I am', } \\
\text { Cuanto antes, mejor ('The sooner, the better')) }\end{array}$ \\
\hline Resultative & $\begin{array}{l}\text { Subj Obj OBL } \mathrm{OP}_{\mathrm{APP}}(\mathrm{e} . \mathrm{g} . \\
\text { Joe painted the barn red.) }\end{array}$ & $\begin{array}{l}\text { Subj, V, DO, SXCOMP } \\
\text { (e.g., Dejó el plato bien limpio ('He left the dish clean'), } \\
\text { Raid los mata bien muertos ('Raid kills them stone dead')) }\end{array}$ \\
\hline Passive & $\begin{array}{l}\text { Subj Aux } \mathrm{VP}_{\mathrm{PP}}\left(\mathrm{PP}_{\mathrm{by}}\right)(\mathrm{e} . \mathrm{g} . \\
\text { the armadillo was hit by a car })\end{array}$ & $\begin{array}{l}\text { Subj, V (Auxiliary + Past participle), Prepositional Phrase } \\
\text { (e.g., El alumno fue premiado por el profesor } \\
\text { ('The student was awarded by the teacher') }\end{array}$ \\
\hline
\end{tabular}

Specifically, the usage-based approach revolves around the claim that the language we learn in our communities is distilled from our exposure to a very large number of examples of usage of that language. It thus entails a fundamentally bottom-up approach to language structure, in which specific local patterns are learned and only later subjected to processes of generalization which give rise to the 'higher' (and more abstract) structures posited in most grammars.

Gonzálvez-García and Butler (2006: 83) suggest a breakdown of the concept of a 'usage-based' model into four component features: (i) Taking usage, synchronic variation and diachronic change as intimately linked; (ii) attempting to account for communicative competence, or rejecting altogether the competence/performance distinction; (iii) allowing for redundant generalizations concerning fully predictable item-specific patterns/expressions, even if these are highly frequent (e.g., I love you); and (iv) making extensive use of data from attested linguistic productions.

Most versions of $\mathrm{CxG}$ are currently usage-based. ${ }^{4}$ The usage-based model states that knowledge of language includes items as well as generalizations, at varying degrees of specificity, while also taking very seriously the creative as well as the formulaic dimensions of language. Usage-based linguistic research has shown that language users store an impressive

\footnotetext{
${ }^{4}$ It should be noted that SBCG embraces the usage-based model, since it is claimed that "linguistic proposals are motivated and evaluated in terms of how well they comport with models of language use (e.g., production and comprehension), language learning and language change" (Sag et al., 2012: 14). However, individual construction grammarians affiliated somehow to SBCG, such as Paul Kay, depart from the usage-based model, thus endorsing the Chomskyan idealization of competence to the detriment of performance (Kay, 2013: 45).
}

amount of item-specific knowledge, including relative frequencies of usage and that they also make generalizations in the form of form-function patterns on the basis of the input they hear. This nicely ties in with the assumption that constructions are learned on the basis of the input, together with domain-general processes including attentional biases, principles of cooperative communication, general processing demands and processes of categorization.

Constructionist approaches are centrally concerned with accounting for all the linguistic phenomena systematically attested in real data and not just the core grammar alone. Although the original impetus of constructionist approaches was on the study of idiomatic constructions (e.g., the let alone-constructions investigated in Fillmore et al., 1988), it should be noted that constructionist grammarians firmly believe that it is only by looking at the properties of idiosyncratic constructions that we can really understand the most general, regular and/or productive aspects of language (see further Gries, 2013).

A monostratal account of grammar is invoked, in which semantic distinctions are associated directly with surface structure. By the same token, no transformations, derivations or empty categories are stipulated. In $\mathrm{CxG}$, the meaning of a particular construct is taken to be the result of the integration (or, alternatively, unification) of the meanings of lexical items into the meaning of the construction(s) as long as these are not in conflict.

Constructionist approaches take explanatory adequacy very seriously. Specifically, $\mathrm{CxG}$ is generative "in the sense that it tries to account for the infinite number of expressions that are allowed by the grammar while attempting to account for the fact that an infinite number of expressions are ruled out or 
disallowed" (Goldberg, 1995: 7; see also Kay, 1997: 124 for a similar position).

CCG, like other cognitively-oriented, usage-based versions of $\mathrm{CxG}$, is strongly influenced by Cognitive Linguistics. By virtue of this, a number of specific claims follow:

(i) The conception of semantics advocated revolves around speakers' construals of situations rather than on objective truth conditions. In addition, a non-classical categorization system based on prototypes and extensions from prototypes is adopted.

(ii) Semantics, information structure and pragmatics are considered to form a continuum, rather than separate modules and they all are assumed to have a bearing on linguistic function.

(iii) A functionalist view of language is favoured insofar as it is claimed that the primary function of language is to convey meaning (Lakoff, 1987: 583). Accordingly, formal distinctions are considered in relation to their potential to express semantic and/or pragmatic distinctions. However, this should not be taken to imply that constructionist grammarians claim that all the constructions in a language can be explained (or motivated) in terms of semantico-pragmatic factors and extralinguistic ones (e.g., iconicity, language processing considerations, etc). In other words, while it is assumed that language is by and large motivated by linguistic as well as extralinguistic factors, it is also acknowledged that there exist pockets of idiosyncrasy which must unavoidably be learned (see Tomasello, 1998: xii).

Social cognition and bodily experience are assumed to play a fundamental role in aspects pertaining to learning and meaning.

From a methodological point of view, it is worth emphasizing that constructionists take descriptive and explanatory adequacy very seriously. In their investigations, they rely on converging evidence from different empirical methods, most notably, naturallyoccurring data in conjunction with introspection, psychological experimentation (sorting, priming, etc) as well as neurolinguistic evidence (Goldberg, 2011).

Constructionists are concerned with providing robust generalizations. In this connection, it must be emphasized that, under the constructional view, the language system is regarded as a structured, hierarchical inventory of constructions in which more basic (or high-level) constructions inherit features from more specific (or lower-level) constructions. To this end, inheritance hierarchies are posited to capture generalizations on the vertical and horizontal relations between higher-level and lower-level configurations in the constructicon. Usage-based, cognitivelyinfluenced versions of $\mathrm{CxG}$, in keeping with the principles of Cognitive semantics, use a default, non- monotonic inheritance system which allows conflicts (or overrides) between the attributes and the values. ${ }^{5}$

Moreover, while cognitively-influenced versions of CG concur with Croft (2001)'s position that constructions are language-specific and that linguistic categories are defined in terms of the constructions they occur in, proposals have been made as to how to posit cross-linguistic generalizations based on constructions. Thus, under the rubric of Contrastive Construction Grammar, Boas (2010) demonstrates that comparing and contrasting constructions between pairs of languages is indeed feasible. Specifically, Boas' (2010) introduction to the volume argues that Frame Semantics (Fillmore, 1985) offers viable tools and methods for comparing how frame elements are realized syntactically in different languages, thereby making it possible to "arrive at cross-linguistic generalizations without losing sight of language-specific idiosyncrasies" (Boas, 2010: 7). One of the ultimate goals is thus to create an inventory of constructions (a "constructicon") for one language, together with their semantic-functional equivalents in other languages. ${ }^{6}$ In addition, it should be noted that, as Goldberg (2013) observes, one of the greatest strengths of (cognitively-influenced) constructionist approaches is that they interface naturally with what is known about language acquisition, language processing, language evolution and cognitive psychology.

Having outlined the major salient features of constructionist approaches (as well as CCG), I will now concentrate on the specifics regarding the treatment of constructions in CCG. The first question that needs to be addressed is that of the division between (i) constructional semantics and (ii) the lexical semantics of the elements filling in the construction and in particular verbal semantics. In this respect, Goldberg's working assumption runs as follows: "the overall interpretation is arrived at by integrating the argument structure construction with the main verb and the various arguments, in light of the pragmatic context in which the clause is uttered." (Goldberg, 2006: 38). In addition, as Goldberg (2006: 10) reminds us, "[c]onstructions are combined freely to form actual expressions as long as they are not in conflict." At a higher level of delicacy, Goldberg posits a number of argument structure constructions in English, which are illustrated in Table 2.

\footnotetext{
${ }^{5}$ By contrast, SBCG invokes the rigid, static, monotonic system (Sag et al., 2012: 14) employed in Minimal Recursion Semantics, which requires that there should be no conflict between attributes and values (see Copestake et al., 2005) and, therefore, cannot in principle accommodate cases of graded membership or prototype effects in particular.

${ }^{6}$ The interested reader is referred to the collection of papers presented in Boas and Gonzálvez-García (2014) for an outline of how (Contrastive) Construction Grammar can provide illuminating insights into the syntax, semantics, pragmatics and discourse-functional properties of specific phenomena in Romance languages in general and Spanish in particular.
} 
Table 2. English argument structure constructions (taken from Goldberg, 1998: 207)

\begin{tabular}{llll}
\hline Construction & Form & Meaning & Example \\
\hline Transitive & Subj V Obj & X acts on Y & Pat opened the door \\
Ditransitive & Subj V Obj1 Obj2 & X causes Y to receive Z & Sue gave her a pen \\
Caused motion & Subj V Obj Obl & X causes Y to move Z & Joe put the cat on the mat \\
Resultative & Subj V Obj Compl & X causes Y to become Z & Kim made him mad \\
\hline
\end{tabular}

Table 3. English light verbs and the constructional meanings they correspond to (Goldberg, 1998: 207)

\begin{tabular}{lll}
\hline Verb & Constructional meaning & Construction \\
\hline Put & X causes Y move Z & Caused motion \\
Make & X causes Y to become Z & Resultative \\
Go & X moves Y & Intransitive Motion \\
Do & X acts on Y & Transitive \\
Get & X acquires/possesses Y & Possessive \\
\hline
\end{tabular}

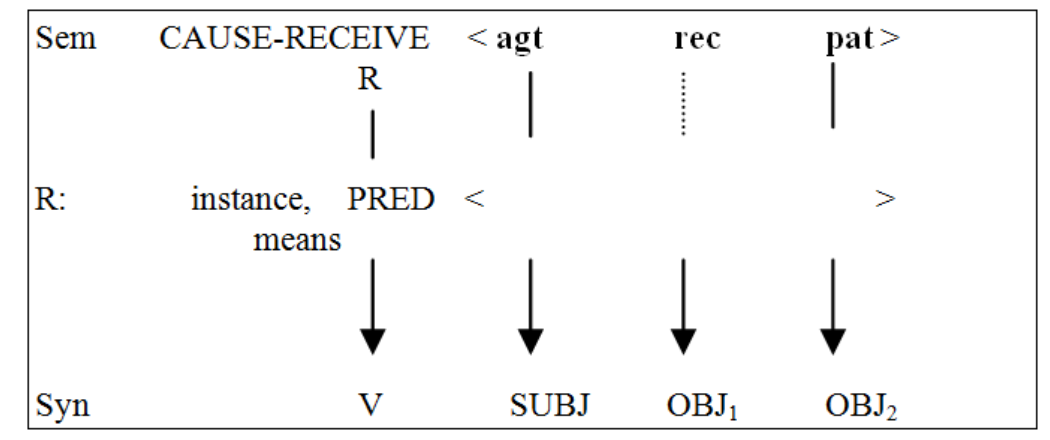

Fig. 1. The anatomy of the English ditransitive construction (Goldberg, 1995: 142)

As was advanced earlier, one of the main attractions of (cognitively-influenced) constructionist approaches is that they are compatible with empirical evidence from language acquisition (Slobin, 1985). Interestingly enough, the basic English argument structure constructions fit in nicely with the (light) verbs that are learned first by English-speaking infants, as shown in Table 3.

In addition, it is claimed that constructions have real psychological plausibility for language users and foreign language learners (Bencini and Goldberg, 2000; Martínez Vázquez, 2004; Valenzuela and Rojo, 2008, inter alios).

In the remainder of this section, I will now go on to examine the anatomy of a construction with specific reference to the Goldbergian system of formalization. Let us consider the case of the English ditransitive construction. Its syntax is usually described as [SBJ VERB OBJ OBJ2]. A representative example of this construction is provided in (9):

(9) When they introduced computers they also taught her typing and keyboard skills (BNC CDK 276)

Goldberg argues that the ditransitive construction contributes the meaning that 'the agent $[\ldots]$ acts to cause transfer of an object to a recipient' (Goldberg, 1995: 32). Thus, example (9) entails that, as the result of a successful transfer of knowledge, the person in question acquired typing and keyboard skills. However, no implication of successful transfer holds in the case of its dative counterpart, as illustrated in (10) below:

(10) When they introduced computers they also taught typing and keyboard skills to her (although she did not become acquainted with these skills)

The anatomy of the English ditransitive construction in the Goldbergian format is reproduced in Fig. 1:

The boxed diagram in Fig. 1 represents the English ditransitive construction, which consists of three different layers: In the top line of the box we find the construction's own meaning (Sem). It contains the semantic arguments of the construction (the constructional roles) and represents their semantic relations with respect to each other. Thus, the English ditransitive construction is associated with the semantics 'X CAUSES Y TO RECEIVE Z.' Solid lines between the semantic roles and the predicate's role array indicate that the semantic role must be fused with an independently existing verbal participant role. Broken lines indicate that the construction is able to provide additional participant roles. The middle line of the construction contains the open slots into which the verb's participant roles fuse and in the bottom line we find the overt syntactic realizations of the semantic 
arguments of the combined verb-construction semantics. Roles represented in bold are 'profiled' arguments, i.e., entities in a verb's semantics that are "obligatorily accessed and function as focal points within the scene, achieving a special degree of prominence (Langacker, 1987)" (Goldberg, 1995: 44).

At a higher level of granularity, it must be emphasized that, according to Goldberg, the general meaning of a given construction is further modulated by the semantics of its components, in particular by the matrix verbs with which they combine. Let us consider now two instances of the ditransitive construction, as in (11)-(12):

(11) (...) Prince gave her a cake with 26 candles on, with the message 'Happy Birthday Darling' in chocolate icing (BNC AA9 581)

(12) (...) Sarah's fiance baked her a cake!www.flickr.com/photos/heydarling/56807662 $98 /$

Thus, while in (11) the verb gave already involves transfer of possession, this meaning component is not present in the inherent lexical semantics of, say, bake. Rather, the meaning of the ditransitive construction with verbs of creation such as bake is that of intended, rather than actual, transfer of possession. Thus, by way of illustration, (11) implies that the recipient got the cake with 26 candles and the Happy Birthday message. By contrast, (12) implies that Sarah's fiancé intended her to receive the cake but he could have dropped it or changed his mind and given it to someone else instead, etc. Thus, it is possible that Sarah did not receive the cake. Goldberg provides a principled account for these otherwise puzzling facts by invoking the notion of constructional polysemy. The same form - a word or a construction - may be associated with different though nonetheless semantically related senses. In the words of Goldberg (1995: 31), "[c]onstructions are typically associated with a family of closely related senses rather than a single, fixed abstract sense" (emphasis added to the original). In the case of the English ditransitive construction, two related meanings can be discerned: Actual transfer of possession and intended transfer of possession. However, Goldberg proposes that the English ditransitive construction actually involves six related constructional meanings, five of which are extensions of the first, central sense (Goldberg, 1995: 38). As shown in (13), the distinct senses of the construction are associated with specific verb classes:

(13) A. Central Sense: agent successfully causes recipient to receive patient

1. Verbs that inherently signify acts of giving: give, pass, hand, serve, feed,...

2. Verbs of instantaneous causation of ballistic motion: throw, toss, slap, kick, poke, fling, shoot,...
3. Verbs of continuous causation in a deictically specified direction: bring, take,...

B. Conditions of satisfaction imply that agent causes recipient to receive patient

1. Verbs of giving with associated satisfaction conditions: guarantee, promise, owe,...

C. Agent causes recipient not to receive patient

1. Verbs of refusal: refuse, deny

D. Agent acts to cause recipient to receive patient at some future point in time

1. Verbs of future transfer: leave, bequeath, allocate, reserve, grant, ...

E. Agent enables recipient to receive patient

1. Verbs of permission: permit, allow

F. Agent intends to cause recipient to receive patient

1. Verbs involved in scenes of creation: bake, make, build, cook, sew, knit,...

2. Verbs of obtaining: get, grab, win, earn,...

The constructional view reflects the general idea that a set of constructions does not consist of independent entities that exhibit irregular organizational patterns, but is instead a "highly structured lattice of interrelated information" in which complex linguistic signs are associated with each other through different types of links (cf. Goldberg, 1995; 2006; Langacker, 1987; 2008; Bybee, 2010; Diessel, 2013), as shown in Fig. 2 for verbargument structure constructions.

This uncompromising focus on robust generalizations among constructions as well as on the idiosyncratic particulars of argument structure is one of the major recurring themes in Goldberg's work to date. In this paper I will show how this emphasis on capturing generalizations and instances (item-specific knowledge) simultaneously is particularly well-suited to provide a principled, unified descriptive and explanatory account of the semantico-pragmatic build ups of secondary predication with decir ('say') in present-day Spanish.

\section{The Subjective-Transitive Construction in Spanish}

The present paper concentrates on a fine-grained constructionist analysis of decir ('say') in instances of secondary predication of the kind illustrated in (1)-(5). Let us start off by addressing what is understood by secondary predication in this study. Consider (14)(a)-(b):

(14) (a) Te encuentro inteligente, divertida, encantadora, sensible, ... -/-> Te encuentro

'I find you intelligent, funny, charming, sensitive, . ..'-/-> 'I find you'

(CREA, 1995, José Donoso, Donde van a morir los elefantes)

(b) Me dicen "tonto" por fumar marihuana :: *Me dicen 
'They call me a fool because I smoke pod' -/-> 'They call me'

https://es-

es.facebook.com/Como.Seria.1939/posts/7511112 54917232

The configurations in (14)(a)-(b) can be provisionally characterized as involving an NP (e.g., te, me) and a predicative phrase (or XPCOMP) which designates a current (i.e., non-resultative) temporary or permanent property of the entity/person encoded in the NP functioning as direct object (i.e., inteligente 'intelligent', divertida 'funny', encantadora 'charming', sensible 'sensitive', tonto 'silly'). It should be emphasized that the XPCOMP displays a high degree of obligatoriness to the extent that its omission yields either an unacceptable result or a dramatic meaning change, as illustrated in (14)(a)-(b) (see further Demonte and Masullo, 1999: 2463, fn. 1 for a synoptic view of alternative terminology).

Gonzálvez-García (2009, 2011) contends that depictive secondary predication instances in Spanish can be taken to form a family of subjective-transitive constructions. Thus, the general constructional meaning $\mathrm{X} \quad\left(\mathrm{NP}_{1}\right) \quad$ EXPRESSES A DIRECT/PERSONAL/ FORCEFUL INVOLVEMENT OVER Y $\left(\mathrm{NP}_{2}\right.$ XPCOMP) of the $\mathrm{NP}_{1} \mathrm{~V} \mathrm{NP} \mathrm{NP}_{2}$ XCOMP frame is further elaborated by the lexical semantics of each verb class. At least four classes of verbs can felicitously fuse with this construction: (i) Verbs of mental processes" in the sense of Halliday (1985: 116-118), comprising the domains of "affection, perception and cognition", (b) verbs of calling, (c) verbs of volition and (d) verbs of preference, thus yielding the four specific constructional senses of the construction listed in (A)-(D) in (15).

(15) A. [[Sbj Considerar.verb Obj XPCOMP $]$ [personal, direct, fully committed evaluation] Por ahora encuentro a Aznar falto de imaginación 'Thus far I find Aznar lacking in imagination' (CREA, Tiempo, 23/04/1990: JOSÉ FEDERICO DE CARVAJAL)

B. [[Sbj Llamar.verb Obj XPCOMP]] [personal, direct, fully-committed verbalization].

Me llaman monstruo pues no puedo salir a la calle

'They call me monster since I cannot leave home' (CREA, Oral, Esta noche cruzamos el Mississippi, 22/10/96, Tele 5)

C. [[Sbj Querer.verb Obj XPCOMP]] [strong, direct/indirect, target-oriented manipulation].

Queremos a Ángel libre

'We want Ángel free'

(CREA, 1985, El País, 02/02/1985: 3.000 personas marcharon en silencio contra el secuestro del industrial)

D. [[Sbj Gustar.verb Obj XPCOMP]] [direct, personal, general preference].

Los caballeros las prefieren rubias (...)

http://www.antena3.com/se-

estrena/noticias/actualidad/caballeros-prefieren-

rubias-ellas-quieren-ser-como-

marilyn_2014080500138.html

'Gentlemen like them blond'

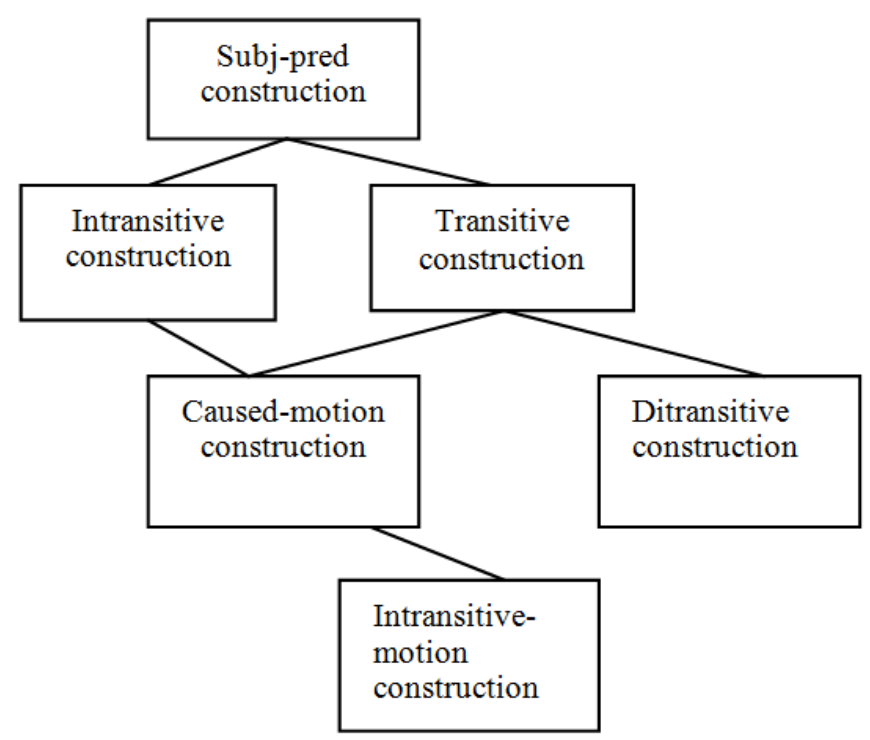

Fig. 2. Network of argument-structure constructions (Goldberg, 1995: 109) 
The term "subjective" should be understood in this paper in a three-fold sense: (i) as referring to the main clause subject/speaker and the degree of involvement implicit in his/her stance towards the proposition; (ii) as being connected with the Traugottian definition of subjectivity (Traugott and Dasher, 2002; see also Lyons, 1982: 102; Scheibman, 2002: 1-16); and (iii) as being connected with evidentiality as in e.g., Chafe and Nichols (1986), in particular with the distinction between direct and hearsay evidence, respectively. These three features can be plausibly subsumed under what De Smet and Verstraete (2006: 387) refer to as "ideational subjectivity". Although the focus on this article is, for practical reasons, primarily on this type of subjectivity, it should be emphasized that in order to fully understand the semantic impact of subjectivity, attention should be paid to the connections between "ideational subjectivity" and "interpersonal subjectivity", understood as "the enactment of speaker's position with regard to its content" (De Smet and Verstraete, 2006: 387). Thus, for instance, "interpersonal subjectivity" may be expected to be a crucial determinant of evidentiality (and certainly of force-dynamic relations in the case of verbs of causation, volition and preference) and may prove indispensable in the reappraisal of "usage-based linguistics as the "micro" end of rhetoric" (Hopper, 2007: 236).

Since only senses (A) and (B) are directly relevant to the object of inquiry of this paper, we will concentrate on these senses of the subjective-construction in Spanish and their lower-level configurations in the discussion that follows.

\section{The Spanish Evaluative Subjective-Transitive Construction}

This constructional sense encodes a decidedly subjective, personal assessment on the part of the subject/speaker (a person) about an entity (a thing or a person) on the basis of first-hand evidence, as shown in (16)-(17). The verbs eligible for occurrence in this subconstruction belong to the group of cognitive and/or physical perception and they share as a common feature the evaluation by the subject/speaker of an object or event/state of affairs. These include: encontrar ('find'), creer ('believe'), pensar ('think'), suponer ('suppose'), ver ('see'), sentir ('feel'), notar ('feel'), etc.

(16) (...) a tu amigo Pepel \#a algún amigo lo encuentro yo un poco raro/*con los ojos azules (Example adapted from CREA, Oral, !Ay! vida mía, 10/06/93, TVE 1)

'I find your friend Pepe/\#some friend a bit strange/*blue-eyed'

a. (\# pero realmente no creo que sea raro)

'but I really do not think that you are a bit strange'

b. (\# pero realmente no tengo evidencia de primera mano para pensar eso) 'but I really do not have any first-hand evidence to think that'

c. aunque otros piensen que no eres nada de eso 'although others may think that you are far from that'

(17) (...) estuvimos en La Toja que la encuentro una ciudad muy artificial, un pueblo muy artificial, (...) (CREA, Oral, MA-3. Mujer de 25 años. Ha estudiado la carrera de piano y canto)

'We visited La Toja, which I found a very artificial city, a very artificial village'

The Spanish evaluative subjective-transitive construction conveys a direct, personal, forceful assessment by the subject/speaker towards the proposition envisioned in the complement clause. Thus, in (16), the subject/speaker's evaluation of the addressee as being a bit strange or funny is the by-product of his direct, personal experience with the addressee, as attested by the non-felicitous result of (16)(a) and (16)(b). In addition, the subject/speaker takes full responsibility for that stance, which may not necessarily coincide with that of other people (see (16)(c)). By the same token, the subject/speaker's assessment of La Toja as a very artificial place in (17) is grounded on his/her personal, direct experience after having visited the place in question. As in the case of (16), the subject/speaker makes a forceful personal claim about this place.

An important observation that needs to concern us here is that the construction imposes non-trivial restrictions on the postverbal NP and the XPCOMP. With respect to the former, the NP must be specific and referential. This is why a non-specific NP such as algún amigo ('some friend') clashes with the first-hand evidence encoded by the construction. ${ }^{7}$ Regarding the XPCOMP, the PP con los ojos azules ('blue eyed') denotes, under normal circumstances, an inherent, objective property that does not lend itself to a subjective construal by the subjectspeaker, hence its ungrammatical result in the evaluative subjective-transitive construction.

Moreover, it must be emphasized that the gamut of verbs eligible to fuse with the evaluative subjectivetransitive construction should be best understood in terms of a gradient or a cline. Thus, at one extreme, we find certain core predicates (e.g., considerar 'consider', encontrar 'find') which match (very) closely the

\footnotetext{
${ }^{7}$ However, it must be noted that indefinite NPs in the postverbal slot yield an acceptable result if stressed (e.g. A algún amigo encuentro yo un poco raro). In cases like these, the topicalized NP also becomes the sentence focus. From a semantico-pragmatic point of view, the implication that arises is that the subject/speaker has a particular person in mind, which means that this prima facie indefinite NP is construed by the subject/speaker as definite and specific, thus being compatible with the constraint imposed by the subjective-transitive construction on the postverbal NP slot.
} 
semantics of the construction. At the other extreme we find other predicates which are systematically repelled by this construction, such as revelar ('reveal') or comprender ('understand'), since they encode the acceptance or uncovering of some sort of state of affairs rather than the forming of an opinion by the subject/speaker, thus clashing with the meaning of the evaluative subjective-transitive construction, in contrast to their perfect acceptability with a finite que-clause, as shown in (18)(a)-(b). ${ }^{8}$ In-between we find predicates which are only acceptable in this construction if coerced into the overall constructional meaning via a reflexive pronoun, such as pensar ('think') (cf. (19)):

(18) (a) Lo considerél encontrél *aceptél *comprendi/*pensé conveniente

'I considered/found/accepted/understood it convenient'

(b) Consideré/Encontré/Acepté/Comprendi/Pensé que era conveniente

'I considered/found/accepted/understood/thought that it was convenient'

(19) Ramón quizá se piensa líder de ese otro fascismo musoliniano y español

(CREA, 1995, Francisco Umbral, Leyenda del César Visionario, Novela)

'Ramón perhaps thinks himself the leader of that other Mussolinean and Spanish fascism'

An even more perplexing case is that of saber ('know'). Specifically, this verb is sensitive to a number of factors: (i) the reflexive or non-reflexive nature of the NP in the object slot, (ii) the human or non-human nature of the NP in the object slot and (iii) whether the XPCOMP denotes a perceivable or evaluative state of affairs. With these observations in mind, the following low-level constructions (or verbspecific constructions in the sense of Croft, 2003) can be posited (see Gonzálvez-García, 2014 for further discussion), as shown in (20)(a)-(b):

(20) (a) 'saber + reflexive + XPCOMP < evaluative state of affairs>'

Se sabe español

'He knows himself to be Spanish'

\footnotetext{
${ }^{8} \mathrm{An}$ important observation qualification is in order here. Just because a verb encodes the expression of an opinion/assessment does not mean that it can fuse with the evaluative subjective-transitive construction felicitously, since lexical idiosyncrasies are nonetheless unavoidable. Thus, as noted by Demonte and Masullo (1999: 2503), the verb opinar ('to be of an opinion') is systematically unacceptable in this construction (e.g. Lo opino conveniente). However, lexical idiosyncrasies of this kind can be accommodated within the moderate view of the semantico-pragmatic motivation of grammar invoked in $\mathrm{CxG}$, as argued in section entitled "The subjective-transitive construction in Spanish".
}

(b) 'saber + NP <+ human $>$ XPCOMP $<$ perceivable state of affairs $>$ '

Le entristecía saber a su hijo en la cárcel

'It made him/her sad to see her son in jail'

The upshot of the acceptability differences illustrated in (18)-(20) is that even higher level configurations such as the evaluative subjective-transitive construction exhibit non-trivial semantico-pragmatic constraints, thus lending support to the claim made in constructionist circles that the regular (or the compositional) and the irregular (or non-compositional) are closely interwoven, thus being two sides of the same coin.

A final observation is in order regarding the impact of subjectivity on the semantic-pragmatic profile of the XPCOMP in this construction. Thus, consider (21):

(21) Considero a Juan tonto/un buen fontanero/\#fontanero/\#perdiendo su tiempo/\#en la habitación 8/en su mejor momento/\#el hombre que está sentado justo ahí

'I consider John silly/a good plumber/plumber /wasting his time/in room 8/at his best/the man who is just sitting right there'

The acceptability contrasts reproduced in (21) can be accounted for as follows: Those categories whose inherent meaning and form properties convey a state of affairs likely to be construed as conveying some sort of evaluation (e.g., gradable adjectives such as tonto, characterizing NPs such as un buen fontanero and PP with a non-literal, figurative meaning, such as en su mejor momento) are felicitous in this slot. By contrast, bare nouns with no evaluative potential (fontanero), gerund clauses, PP with a literal, locative meaning and identifying expressions (el hombre que está sentado justo ahi) clash with the subjective, evaluative meaning of the construction, thus yielding an unacceptable result.

\section{The Spanish Denominative Subjective-Transitive Construction}

Under normal circumstances, combinations of this type express a pragmatically cancellable (ritualised or non-ritualised) verbalization of the ascription of a property by the main clause subject/speaker to the (human or non-human) entity encoded in the object slot. This subconstruction is attested with verbs of calling/saying, such as e.g., llamar ('call'), decir ('say'), denominar ('label'), etc., as in (22):

(22) (...) ambos me dicen incoherente, errático, ambicioso, vanidoso, egocentrista, mercurial, impredecible, traficante de drogas etcétera etcétera, loco

(CREA, Oral, El perro verde, 07/05/88, TVE 1, Entrevistas) 
'They both call me incoherent, erratic, ambitious, conceited, egocentric, mercurial, unpredictable, drug dealer, etc., etc., mad/*the man who's sitting right there.'

a. (\#pero ellos no piensan de verdad que yo sea todo eso

(\#'but they do not really think that I am all that')

b. (\#pero no tienen evidencia alguna de primera mano para afirmar eso)

(\#'but they do not have any first hand evidence to say so')

c. (pero realmente no piensan eso de mí - están de broma)

('but they really do not think that about me - they are just joking')

In much the same vein as the evaluative subjective-transitive construction, this one encodes the ascription of a property by the subject/speaker to the entity encoded in the NP. Therefore, the XPCOMP must have a characterizing, evaluative-like flavour, a requirement that is met by the string of XPCOMPs in (22). From a conversational point of view, this subconstruction implies that the subject/speaker's assessment is based on direct evidence and that the subject/speaker is fully committed. However, the interpretation of (22) can be conversationally cancelled, given an adequate supporting context (e.g., the speaker knows that these people are only joking but they do not really think that, as in (22)(c)).

As in the case of the evaluative subjective-transitive construction, similar semantico-pragmatic restrictions are operational on the XPCOMP slot in this construction, as shown in (23):

(23) Me dicen/llaman loco/traficante de drogas/\#fontanero/\#perdiendo mi tiempo/\#el hombre que está sentado justo ahí

'They call me mad/drug dealer/a plumber/wasting my time/the man who's just sitting right there'

\section{The Reflexive Subjective-Transitive Construction}

This section will be concerned with the analysis of partially-filled configurations of secondary predication in which the postverbal NP slot is realized by a reflexive pronoun, as in (24)-(25): ${ }^{9}$

(24) (a) (En una reciente entrevista) Salma Hayek se dice amante de los perros

'In a recent interview, Salma Hayek declares herself fond of dogs'

${ }^{9}$ For detailed accounts of reflexive constructions in Spanish, the reader is referred to García (1975), Faltz (1977), Martín Zorraquino (1979), Vera Luján (1996-1997), Maldonado (1999) and Sánchez López (2002: 74-49), inter alios.
(El Pais, 02/02/2004)

(b) *En una reciente entrevista Salma Hayek dice a su hija amante de los perros

(25) (a) (...) ruégale que los que nos (...) decimos amigos de Dios lo seamos de veras y a todas las horas (CREA, 1986, José María Escrivá Balaguer, Surco) 'Pray to her that those of us who call ourselves friends of God be truly so and at any time'

(b) \#Ruégale para que a esos hombres que decimos amigos de Dios no les falte nunca la fe.

'Pray to her that those men whom we call friends of God are never found lacking in faith'

In the light of examples (24)-(25), two important observations need to be made. First, the occurrence of the reflexive pronoun in the postverbal NP slot saves an otherwise unacceptable result, as illustrated in (24)(b) and $(25)(b)$. Second, the reflexive pronoun coerces the overall interpretation of the configuration into that of self-evaluation, in relative independence of the lexical semantics of the matrix verb (e.g., confesar ('profess'), declarar ('declare'), decir ('say')). In other words, the verba dicendi which occur in this construction (see Table 4) are invariably construed as considerar ('consider')-type verbs, regardless of whether their inherent lexical semantics encodes little or no evaluation at all, thus providing incontrovertible empirical evidence for the priority of constructional semantics over lexical semantics. Thus, it is possible to regard configurations like (24)-(25) as instances of the reflexive subjective-transitive construction (see further Gonzálvez-García 2007; 2008; 2009), which can be characterized as follows:

\section{The reflexive subjective-transitive} construction: The subject/speaker $\left(\mathrm{NP}_{1}\right)$ expresses a (non-cancellable) direct, personal, categorical judgemental stance (XPCOMP) about himself/herself $\left(\mathrm{NP}_{2}\right)$.

(26) Salma Hayek se dice amante de los perros (a) \#pero en realidad, en opinión de la propia Salma, ella no es amante de los perros

'but in actual fact, in Salma's opinion, she is not a lover of dogs'

(b) \#pero ella no tiene evidencia alguna de primera mano para pensar eso

'but she does not really have any first-hand evidence to think so'

At a higher level of delicacy, it must be emphasized that, while decir ('say'), declarar ('acknowledge'), confesar ('acknowledge') and reconocer ('acknowledge') can felicitously occur in the reflexive subjective-transitive construction, this statement cannot be duplicated for all verba dicendi, as shown in (27): 
(27) Salma Hayek se dice/declara/confiesa/reconoce *anuncia/*pronuncia/?afirma amante de los perros $^{10}$

'She claims/acknowledges/professes herself a lover of dogs'

Interestingly enough, it must be noted that certain XPCOMPs are more likely to be combined with particular verba dicendi in present-day Spanish, as shown in Table 5.

In addition, some of the collocates attested in our data are more flexible with respect to the choice of the matrix verb than others, which are lexically-bound, as illustrated in (28)(a)-(b), respectively:

(28) (a) decirse/ declararse/ confesarse/ ?? reconocerse dispuesto a hacer algo

'to declare oneself willing to do something'

(b) declararsel *decirsel \#confesarsel \#reconocerse en huelga

'to declare oneself on strike'

Finally, as in the case of the higher-level evaluative subjective-transitive construction and the denominative subjective-transitive construction, only those XPCOMPs whose inherent meaning and form properties are compatible with a subjective and thus evaluative construal are felicitous in this lower-level configuration, as shown in (29):

(29) Se dice/reconoce buen lector/un Casanova/*en Londres/*jugando al tenis/*el hombre que está sentado justo ahi

'He acknowledges himself to be a good reader/a Casanova/in London/playing tennis/the man who is just sitting right there'

\section{The Spanish Imperative Subjective-Transitive Construction}

Most verba cogitandi as well as verba dicendi et declarandi, when used in the secondary predication frame to express judgement or evaluation on the part of the subject/speaker, disallow or resist a dynamic interpretation, which explains their incompatibility with imperative verb forms (cf. (30)(a)-(d) below). By contrast, their primary predication counterparts, which encode a pure process of cognition or saying with no evaluation on the part of the subject/speaker, are

\footnotetext{
${ }^{10}$ It should be pointed out that the combination afirmarse capaz de algo, while not attested in the CREA corpus, is nonetheless acceptable in present-day Spanish in the reflexive subjective-transitive construction. Thus, consider: Él se afirma capaz de perdonar los pecados 'He claims himself to be capable of forgiving sins' (http://jonihl.wordpress.com/consulta/).
}

perfectly acceptable in the imperative, as illustrated in (31)(a)-(b) below:
(30) (a) \#Encuentra esta novela una obra maestra
'Find this novel a masterpiece'
(b) \#Cree a tu hermano un buen escritor
'Believe your brother a good writer'
(e) \#Llama a tu profesor egoísta
'Call your professor selfish'
(d) \#Dí a tu profesor ingenuo
'Call your professor naïve'

(31) (a) Y créeme: vivir merece la pena (. . .)

(CREA, 2003, Prensa, Revista Natural, n ${ }^{\circ} 45$, 03/2003: Sobre la depresión, Psiquiatría, Naturalmente Natural (Madrid))

'And, believe me, life is worth living'

(b) De todas maneras, llámame y hablamos ahora

(CREA, Oral, Contestador automático privado, Madrid, 08/07/91 a 29/07/91)

'In any case, call me and we'll talk now'

However, llamar ('call') and decir ('say') can be coerced into the secondary predication frame via the imperative form. In this case, coercion obtains because the lexical semantics of the matrix verbs in question ends up conforming to the imperative secondary frame, thus shifting from the expression of the ascription of a property involving no control on the part of the subject/speaker to some sort of invitation or request by the Speaker to the Hearer, as in (32)-(33):

(32) Sí, sí, dime prostituta, si prostituta es la mujer que siente

(CREA, 1986, Miguel Murillo Gómez, Custodia y los Gatos, Teatro)

'Ok, fine, call me a prostitute, if a prostitute is a woman who has feelings'

(33) Llámame cabrón, hijo puta, mal padre, beato, puerco, papá, dime algo hija, pero dímelo

(CREA, 1982, José Luis Alegre Cudós, Minotauro a la cazuela, Teatro)

'Call me motherfucker, son of a bitch, a bad father, sanctimonious, a pig, daddy, call me whatever, daughter, but say it to me'

In all the cases above, what motivates the occurrence of these verbs in the secondary predication frame is that the Speaker anticipates, at least in principle, a direct, personal, categorical (i.e., forceful) stance on the part of Hearer either about him/her or a deictic entity (i.e., lo, as in e.g., Llámalo $X$ 'Call it X') with a topic status in the discourse flow. The constructional semantics of this lower-level configuration can be established as follows: 


\section{The imperative subjective-transitive} construction: The speaker directs the hearer towards a prospective cognitive mode (ranging from a warning to an invitation or instruction, etc.), anticipating a direct, personal, categorical (i.e., forceful) judgemental stance on the part of the hearer either about the speaker or a deictic entity with a topic status in the discourse flow.

In the case of the imperative subjective-transitive construction showing coercion effects with verba dicendi, we can see that llamar ('call') exhibits a higher degree of productivity than decir ('say'), as shown in Table 6.

Table 4. Distribution of verba dicendi subject to coercion in the reflexive subjective-transitive construction in the CREA (listed in decreasing order of frequency) ${ }^{11}$

\begin{tabular}{|c|c|c|}
\hline Verb & Rate $\%$ & Tokens \\
\hline DECLARAR ('profess') & 64.65 & 311 \\
\hline CONFESAR ('acknowledge') & 19.12 & 92 \\
\hline DECIR ('say') & 11.43 & 55 \\
\hline RECONOCER ('acknowledge') & 4.78 & 23 \\
\hline TOTAL & 100.00 & 481 \\
\hline
\end{tabular}

Table 5. Distribution of the most frequent collocates with verba dicendi subject to coercion in the reflexive subjective-transitive construction in Spanish in the CREA (listed in alphabetical order) (taken from Gonzálvez-García, 2008: 305)

\begin{tabular}{|c|c|c|c|}
\hline Verb & Combination & Rate $\%$ & Tokens \\
\hline \multirow[t]{3}{*}{$\begin{array}{l}\text { CONFESAR } \\
\text { ('acknowledge') }\end{array}$} & $\begin{array}{l}\text { Confesarse culpable } \\
\text { 'to acknowledge oneself guilty' }\end{array}$ & 50.00 & 10 \\
\hline & $\begin{array}{l}\text { Confesarse autor de } \\
\text { algo (e.g., crimen, } \\
\text { fraude, muerte) 'to } \\
\text { acknowledge oneself the perpetrator of } \mathrm{X} \text { ' } \\
\text { (e.g., a crime, fraud, murder) }\end{array}$ & 50.00 & 10 \\
\hline & TOTAL & 100.00 & 20 \\
\hline \multirow[t]{3}{*}{$\begin{array}{l}\text { DECIR } \\
\text { ('declare'/ } \\
\text { 'call') }\end{array}$} & $\begin{array}{l}\text { Decirse dispuesto a } \\
\text { hacer algo 'to declare } \\
\text { oneself willing to do } \\
\text { something' }\end{array}$ & 55.55 & 5 \\
\hline & $\begin{array}{l}\text { Decirse católico- } a \text { 'to } \\
\text { call oneself a Catholic' }\end{array}$ & 44.45 & 4 \\
\hline & TOTAL & 100.00 & 9 \\
\hline \multirow[t]{3}{*}{$\begin{array}{l}\text { DECLARAR } \\
\text { ('profess') }\end{array}$} & $\begin{array}{l}\text { Declararse dispuesto a } \\
\text { hacer algo 'to profess } \\
\text { oneself willing to do } \\
\text { something' }\end{array}$ & 59.45 & 22 \\
\hline & $\begin{array}{l}\text { Declararse en huelga } \\
\text { 'to declare oneself on } \\
\text { strike' }\end{array}$ & 40.15 & 15 \\
\hline & TOTAL & 100.00 & 37 \\
\hline \multirow[t]{2}{*}{$\begin{array}{l}\text { RECONOCER } \\
\text { ('acknowledge') }\end{array}$} & $\begin{array}{l}\text { Reconocerse incapaz } \\
\text { de algo 'to acknowledge } \\
\text { oneself incapable of } \\
\text { something' }\end{array}$ & 100.00 & 3 \\
\hline & TOTAL & 100.00 & 3 \\
\hline
\end{tabular}

Table 6. Distribution of verba dicendi subject to coercion in the imperative subjective-transitive construction in Spanish in the CREA (listed in descending order of relative frequency)

\begin{tabular}{lcr}
\hline Verb & Tokens & Rate \% \\
\hline LLAMAR ('call') & 30 & 90.90 \\
DECIR ('call','say') & 3 & 9.09 \\
TOTAL & 33 & 100.00 \\
\hline
\end{tabular}

\footnotetext{
${ }^{11}$ The data reproduced in Tables 4-7 consists of 855 tokens out of a total of 9,720 tokens of verba cogitandi et dicendi in the secondary predication frame sampled from the in the CREA sampled from the following categories: Ciencia y Tecnología ('Science and Technology') and Ciencias Sociales ('Social Sciences'). All the tokens extracted were found exclusively in the latter category.
} 
In our data, decir ('say') is almost invariably found in the imperative subjective-transitive construction in the proverb reproduced in (34):

(34) Dame pan y dime tonto

(CREA, Oral, Vehículo público, conversación entre pasajeros, Madrid-Barajas, 30/06/91)

'Give me bread and call me a fool'

What is particularly interesting for our purposes here is that, despite its fixed status, this proverb serves as a template for analogical innovative extensions on the part of language users in present-day Spanish, as shown in (35)(a)-(d) ${ }^{12}$ :

(35) (a) Dame pan y llámame tonto

'Give me bread and call me a fool'

(b) Dame pan y dime calvo

'Give me bread and call me bold'

http://interiornoche.com/2004/10/clive-arrindelldame-pan-y-dime-calvo.html

(c) Dame pan y dime "vendio"

'Give me bread and call me a traitor' http://abcblogs.abc.es/musica/public/post/damepan-y-dime-vendio-10014.asp/

(d) Dame posts y dime friki

'Give posts and call me freak'

http://damepostsydimefriki.tumblr.com/

Configurations like the ones reproduced in (35)(a)(d) lend further credence to Bybee and Torres Cacoullos' (2009: 188) contention that fixed expressions and productive formations are actually the two poles of a continuum in the constructicon.

A final observation is in order here regarding the importance of subjectivity in determining the degree of acceptability of the element in the XPCOMP. As in the case of the higher-level subjective-transitive construction, the XPCOMP must encode a judgemental stance on the part of the subject/speaker regarding the entity in the object slot in order to ensure compatibility with the constructional meaning, as is the case with characterizing predicate nominals (e.g., tonto 'silly') - including nicknames (e.g., Paco) - and predicate adjectives (e.g., sentimental 'sentimental'). By contrast, those categories such as PPs (e.g., en Londres/'in London') and Adverbial Phrases (e.g., alli 'there') with a literal locative meaning, gerund clauses with dynamic reading (e.g.,

\footnotetext{
${ }^{12}$ In addition, it must be noted that this is a low frequency proverb in Spanish. See further http://cvc.cervantes.es/lengua/refranero /ficha.aspx?Par=58429andLng=0.
}

perdiendo mi tiempo/'wasting my time') and NPs with an identifying referential value (e.g., el hombre que está ahi ahora/'the man who is right there now') invariably yield an unacceptable result in this construction. Thus, consider (36):

\section{Llámame/Dime tonto/ Pedro/ \#en Londres/ \#perdiendo mi tiempo/\#el hombre que está ahi/\#ahora}

'Call me a fool/Pedro/in London/wasting my time/the man who is right there now/there'

By way of interim conclusion of our discussion of the subjective-transitive constructions in the active voice, Fig. 3 reproduces the anatomy of this construction in a Goldbergian format. Drawing on Gonzálvez-García (2009), this figure also builds into the anatomy of the construction fine-nuanced semantic restrictions for the semantic roles of the construction as well as morphosyntactic information mapped onto semantico-pragmatic properties for the syntactic functions of the construction's components. This additional information is meant to enhance the explanatory and generative power of constructions by providing a principled account of the acceptability contrasts impinging on the XPCOMP in this construction. $^{13}$

\section{The Spanish Impersonal Subjective-Transitive Construction}

Thus far we have been concerned in the preceding three sub-sections with instances of secondary predication after verba dicendi in the active voice at varying levels of specificity. However, verba dicendi in general and decir ('say') in particular are felicitous in (reflex) passive configurations of the kind exemplified in (37)-(39): ${ }^{14}$

(37) (a) La exposición aludida mostraba los argumentos del desarrollo de una disciplina tradicionalmente apegada en exceso al material y al modelo, cuyo énfasis vanguardista, en nuestro siglo, se admite posterior al de la pintura

(CREA, Prensa, ABC Cultural, 15/11/1996: MANUAL DE ESCULTURA DEL SIGLO XX)

'The above-mentioned exhibition showed the arguments for the development of a discipline

\footnotetext{
${ }^{13}$ The interested reader is referred to Gonzálvez-García (2009) for the anatomies of the other constructions surveyed in this paper.

${ }^{14}$ For further details on the passive construction and the reflex passive in Spanish, the reader is referred to Mendikoetxea (1999), Sánchez López (2002), Fernández (2007) and Ruiz de Mendoza Ibáñez and Peña Cervel (2008), inter alios.
} 
traditionally excessively biased towards the material and the model, whose avant-garde emphasis in our century is admitted to be posterior to that of painting'

(b) *La exposición aludida mostraba los argumentos del desarrollo de una disciplina tradicionalmente apegada en exceso al material y al modelo, cuyo énfasis vanguardista, en nuestro siglo, algunos admiten posterior al de la pintura

(38) (a) Y si resulta que ese comportamiento se dice "ignorado" por todos sus mandos

"And if it turns out that that behaviour is said to be 'ignored' by all his superiors'

(CREA Corpus, 1995, Cristina Almeida, Carta abierta a una política honrada sobre la corrupción) (b) *Y si resulta que algunos dicen ese comportamiento "ignorado" por todos sus mandos

(39) (a) (...) en alemán se escribe mit Karacho (pronúnciese la ch como en Bach) para lo que en español coloquial se dice a todo gas (...)

'In German one writes mit Karacho (you should pronounce the "ch" as in Bach) for what in colloquial Spanish would be described as a todo gas'

(CREA Corpus, 1997, ABC Electrónico, 22/09/1997: Tercera: no todo es inglés)

(b) en alemán uno escribe mit Karacho (pronúnciese la ch como en Bach) para lo que en español coloquial uno dice a todo gas (...)

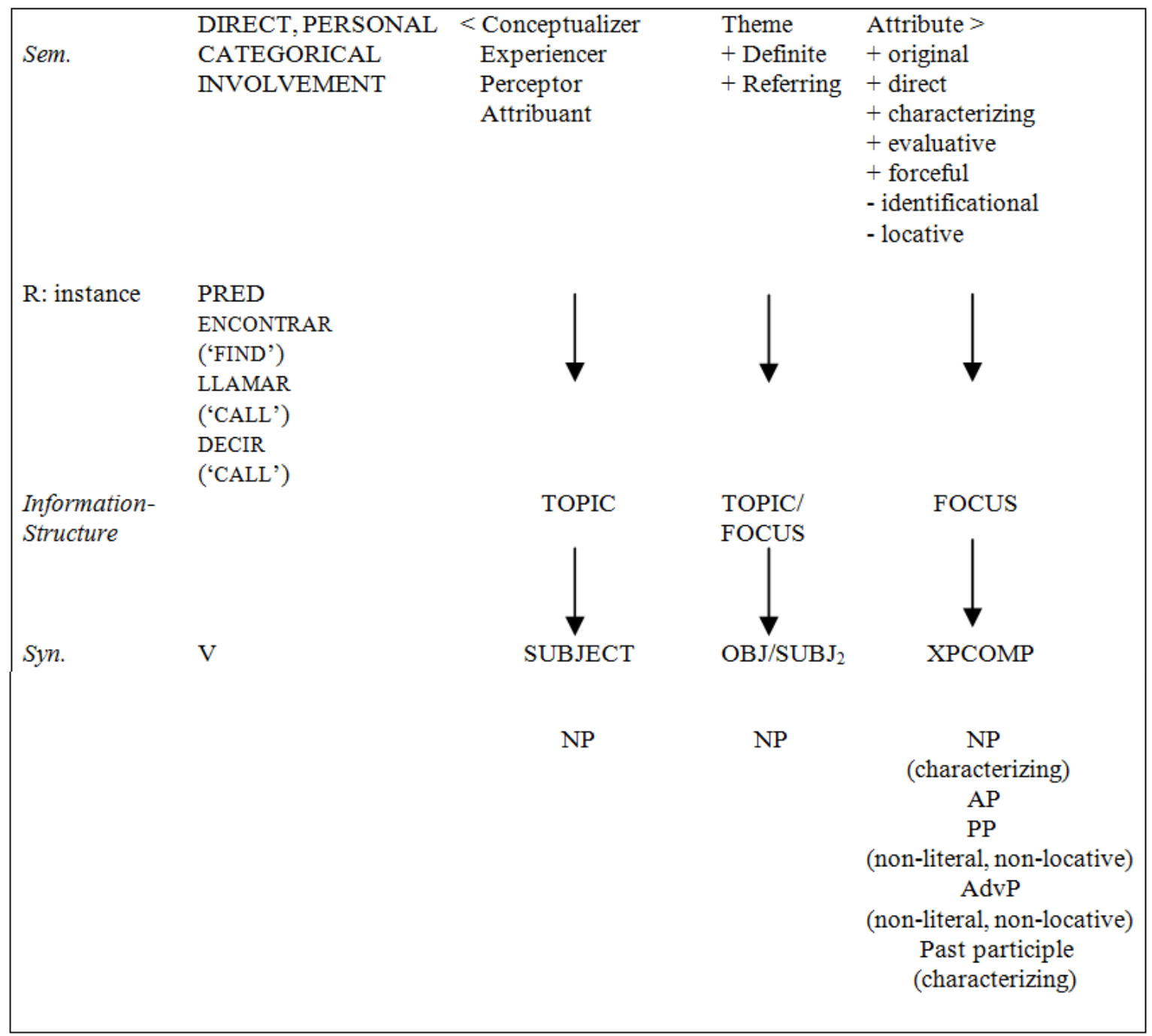

Fig. 3. The anatomy of the subjective-transitive construction 
However, an important difference between the configurations in (38)-(39) and those analyzed in the preceding three sub-sections is that a coercive passive clitic se coexists (cf. (38)(b)) with a non-coercive passive clitic se (cf. (39)(b)) in the secondary predication frame. ${ }^{15}$ In fact, Gonzálvez-García (2006) shows that the occurrences with decir ('say') in secondary predication in the passive can be best seen in terms of a three-point continuum between (i) non-grammaticalized (compositional) configurations with an active counterpart, (ii) non-grammaticalized constructions without an active counterpart and (iii) grammaticalized (non-compositional) configurations without an active counterpart, as illustrated in (40)-(42), respectively:

(40) (...) en alemán se escribe mit Karacho (pronúnciese la ch como en Bach) para lo que en español coloquial se dice a todo gas (...)

'In German one writes mit Karacho (you should pronounce the "ch" as in Bach) for what in colloquial Spanish would be described as a todo gas'

(CREA Corpus, 1997, ABC Electrónico, 22/09/1997: Tercera: no todo es inglés)

In configurations of this type, the se-clitic is more likely than not to be construed as an actor of the action encoded in the verb, which explains among other things why an impersonal interpretation (e.g., En alemán uno escribe mit Karacho para lo que uno dice en español colloquial a todo gas, 'In German one writes mit Karacho for what one would describe in colloquial Spanish as a todo gas') is feasible here. In addition the matrix verb dice (lit. 'says') can be paraphrased as llama (lit. 'calls').

The second point in the continuum is illustrated in (41)(a), where the passive form se dice (lit. 'is said') can be rephrased as se considera (lit. 'is considered') and yields an unacceptable result if turned into the active (cf. (41)(b)).

(a) Continúa el misterio de Agustina Izquierdo, esa escritora fantasma que se dice hija de exiliados españoles

'There still remains the mystery of Agustina Izquierdo, that ghost writer who is said to be the daughter of exiled Spaniards'

(CREA Corpus, 1996, ABC Cultural, 08/03/1996: El amor puro)

(b) \#Continúa el misterio de Agustina Izquierdo, esa escritora fantasma que algunos dicen hija de exiliados españoles

\footnotetext{
${ }^{15}$ It is indeed possible to consider as cases of coercion the instances of the impersonal subjective-transitive construction which do not have a felicitous active counterpart, regardless of whether these are grammaticalized or not. The interested reader is referred to Bisang (2011: 109) and Gisborne and Patten (2011), inter alios, for the relevance of coercion to handle grammaticalization and constructional change in a constructionist framework.
}

Finally, the last type within this three-stage continuum is illustrated in (42), where the passive matrix string se dice ('is said'), unlike the examples reproduced in (40) and (41) above, illustrates the case of a free syntactic structure, viz. a nominal relative clause, which has undergone an early process of grammaticalization observable among other things in a shift of the original processual meaning to develop into (i) a subjunct (focusing/emphasizer) as well as (ii) a summative reformulatory conjunct (Quirk, 1985: 631-647), as argued in some detail in the next section. However, in much the same vein as the configurations of the kind in (42), an active counterpart is invariably non-felicitous here.

(42) (a) Mr John Spencer no era lo que se dice un hombre intachable

'Mr John Spencer was not what you may call an irreproachable man'

(CREA Corpus, 1980, Anónimo, Los tripulantes de ovnis)

(b) \#Mr John Spencer no era lo que uno dice un hombre intachable

The existence of a three-fold continuum with decir ('say') in the passive secondary predication is consonant with the relative higher frequency of this verb with respect to other verba dicendi in this environment, as shown in Table 7.

To round off this section, some observations are in order regarding the status of the passive as a construction. As will be recalled from Table 1, taken from Goldberg (2006: 5), passives qualify as constructions in their own right on the grounds that they differ from actives in terms of information structure, that is, the normally most prominent argument - the notional subject - is backgrounded. In this connection, it must be emphasized that the se-passives under scrutiny here are not only agent-less but seem to disallow the insertion of an agent adjunct, as shown in (43):

(43) \#Continúa el misterio de Agustina Izquierdo, esa escritora fantasma que se dice por algunos hija de exiliados españoles

Table 7. Distribution of verba dicendi occurring exclusively in the passive secondary predication configuration in the CREA (listed in descending order of frequency)

\begin{tabular}{lrc}
\hline Verb & Tokens & Rate \% \\
\hline DECIR ('say') & 232 & 92.08 \\
AFIRMAR ('affirm') & 6 & 2.40 \\
ADMITIR ('admit') & 5 & 2.00 \\
RECONOCER ('acknowledge') & 3 & 1.20 \\
ANUNCIAR ('announce') & 3 & 1.20 \\
ALEGAR ('allege') & 1 & 0.40 \\
TOTAL & 250 & 100.00 \\
\hline
\end{tabular}


This striking disparity concerning the expression of the agent in actives and passives as well as the apparently inexplicable acceptability contrasts in (40)-(42) above, can be shown to be semantically motivated if passives are agreed to be constructions - viz. pairings of form with semantic or discourse function (Goldberg, 1995: 7; 2006: 5). Thus, it is only by considering the distancing effect alluded to above as an intrinsic semantico-pragmatic feature of what may be considered a "passive of opinion" (Wierzbicka, 1988: 47) that one may begin to understand the asymmetries at hand here. Specifically, actives highlight the involvement of the subject/speaker towards the content of the clause, whereas passives de-emphasize such involvement in favour of a semblance of impersonality and/or objectivity.

Given the semblance of impersonality intrinsic to the passive, it comes as no surprise that the personal involvement inherent to the secondary predication in the active voice (cf. the Subjective-Transitive construction) is replaced in the characterization of secondary predication passives by an impersonal involvement, which can be further motivated in terms of the systematic absence of the agent-adjunct complement in se-passives in general and the asymmetrical passives under analysis here in particular. This general characterization also fits in nicely with the observation that $s e$-passives in Spanish are well-suited for the expression of a general statement in contrast to, say, the dynamic punctual reading commonly associated with periphrastic passives (see further Fernández Ramírez, 1987: 410-429; Sánchez López, 2002: 52-53, inter alios). However, the direct, categorical (forceful) involvement features associated with the SubjectiveTransitive construction are shared by the corresponding passive secondary predication configurations. With these observations in mind, the skeletal constructional meaning of the Impersonal Subjective-Transitive construction can be established as follows: ${ }^{16}$

\section{The Impersonal Subjective-Transitive construction: $\mathrm{X}\left(\mathrm{NP}_{1}\right)$ is attributed $\mathrm{Y}$ (XPCOMP) by $\mathrm{Z}\left(\mathrm{NP}_{2}\right)$ in a direct, categorical way.}

Thus, in the light of such a constructional characterization, a slightly modified version of sentence (41)(a) above, reproduced below as (44) for expository convenience, can, under normal circumstances, be interpreted as expressing the speaker's endorsement of a forceful general statement and/or judgement about the entity (a person or a thing) encoded in the preverbal NP functioning as the grammatical subject of the passive construction.

\footnotetext{
${ }^{16}$ The interested reader is referred to Gonzálvez-García (2006) for a formalization of the Impersonal Subjective-Transitive construction.
}

(44) Agustina Izquierdo se dice hija de exiliados españoles

(\#pero la gente no la considera realmente hija de exiliados españoles)

(\#pero la gente no tiene evidencia de primera alguna para pensar eso)

Crucially for our purposes here, it must be noted that the XPCOMP in instances of the Impersonal SubjectiveTransitive construction are subject to the same restrictions in terms of subjectivity as the SubjectiveTransitive construction and the lower-level configurations already discussed, as shown in (45):

(45) Esa mujer se dice una escritora fantasma/hija de exiliados españoles/*Agustina Izquierdo/ *perdiendo su tiempo/*alli

'That woman is said to be a ghost female writer/ the daughter of exiled Spaniards/Agustina Izquierdo/wasting her time/there'

At this stage, an important distinction must be pointed out between the passive secondary predication in (41) and that of (42), namely, the fact that se dice displays in (41) a higher transparency of meaning than in (42). As a matter of fact, the lo que se dice string in (42) has developed some semantico-pragmatic nuances and changes that distance it from the more general (i.e., literal) construction with which it is related, illustrated in (46):

(46) (...) Al contrario de lo que se dice, no existen palabras vacías

(CREA, Prensa, El Diario Vasco, 03/06/2001: La obra es un "acto de rebeldía")

'Contrary to what is often said, there are no empty words'

\section{The lo que se dice XPCOMP Construction in Present-Day Spanish}

In the remainder of this paper we will be concerned with a constructionist analysis of instances of lo que se dice followed by an XPCOMP as in (47)-(48):

(47) Mr John Spencer no era lo que se dice un hombre intachable

(CREA Corpus, 1980, Anónimo, Los tripulantes de ovnis)

'Mr John Spencer was not what you may call an irreproachable man'

(48) Lo que se dice un ídolo (book title) http://www.books.google.es/books?isbn=9506653 410

'Definitely an idol' 
The material on which this section is based consists of 206 instances of grammaticalized instances of the $l o$ que se dice XPCOMP construction out of 232 tokens of se dice ('is said') in the secondary predication configuration $(88.72 \%)$ in the CREA sampled from the following categories: Ciencia y Tecnología ('Science and Technology') and Ciencias Sociales ('Social Sciences'). All the tokens extracted were found exclusively in the latter category.

Lo que se dice XPCOMP configurations are particularly interesting for two reasons: (i) these are especially productive within passive secondary predication configurations with se dice, accounting for an $80 \%$ of the total distribution for this verb (cf. Table 7) and (ii) configurations of this type feature a prominent degree of syntactico-semantic versatility which can be conflated into two major functions: (i) a restrictive focusing and/or emphasizer subjunct (Quirk, 1985: 610612; Fuentes, 1991; Fernández Lagunilla and De Miguel, 2000, inter alios) (cf. (47)) and (ii) a connective discourse marker with a summative function roughly equivalent to en definitiva ('in short') or o sea ('that is') (cf. (48)).

The overarching assumption made in this section is that the lo que se dice XPCOMP construction is an incipient case of grammaticalization. At this stage, some considerations are in order regarding the notion of grammaticalization with special focus on the construction under scrutiny here, to which we turn in the next sub-section.

\section{The lo que se dice XPCOMP Construction as a Case of Incipient Grammaticalization}

Grammaticalization is generally understood to be the process whereby linguistic items (of a lexical, pragmatic or even phonetic nature) become grammatical or whereby already grammatical items achieve an even more grammatical status, changing their distribution and function in the process (cf. Hopper and Traugott, 1993: xv; Lehmann, 1995; 2002: 10; Heine et al., 1991; Bybee, 2003a: 146; Hopper and Traugott, 2003; Narrog and Heine, 2011, inter alios).

Within this general scenario, some researchers working on grammaticalization have prioritized the morphosyntactic dimension of the phenomenon, thus equating grammaticalization with increased morphosyntactic fusion and loss of syntactic freedom (see e.g., Lehmann, 1995; 2002). By contrast, recent work into grammaticalization by Bybee and Traugott, inter alios, has adopted an essentially pragmatic perspective which emphasizes the role of an appropriate context for the phenomenon of grammaticalization. In particular, the notion of subjectification, viz. "the development of a grammatically identifiable expression of Speaker's belief or Speaker's attitude towards what is said" (Traugott, 1995a: 32; cf. also Traugott, 1988;
Traugott and Dasher, 2002: 30; Company Company, 2008: 203), is argued to play a crucial role in grammaticalization. Both subjectification and increase in pragmatic meaning (or, alternatively, pragmatic strengthening) are taken "to arise out of the cognitive and communicative pragmatics of speaker-hearer interactions and discourse practices (Langacker, 1987; Du Bois, 1985) via invited inferencing" (Traugott, 2003: 634). Moreover, proponents of this model take a firm stand on the investigation of semantic loss and bleaching for grammaticalization (Bybee, 2003a; 2003b; Traugott, 1988; 1995a; 1995b; 2003; Heine, 2003), which has led to show, among other things, that the early stages of grammaticalization are characterized by an increase in pragmatic force and subjective expressiveness (Hopper and Traugott, 1993: 68; Traugott, 1988; 1995a; 1995b; 2003). Thus, Bybee (2003a; 2003b; 2006), Heine (2003) and Traugott (2003) have highlighted the centrality of constructions to the context-induced view of grammaticalization, thus arguing that "grammaticalization of lexical items takes place within particular constructions and [...] that grammaticalization is the creation of new constructions." (Bybee, 2003a: 146; 2003b: 602; Diewald, 2006; Gisborne and Patten, 2011). Together with the semantico-pragmatic context in which the construction is used, frequency is invoked within this model as a crucial factor for the description as well as the explanation of synchronic states and diachronic changes (e.g., Hopper and Traugott, 1993; Bybee et al., 1994; Bybee and Hopper, 2001, inter alios). In particular, within the general background of grammaticalization as a form of routinization of language (Haiman, 1991), it has been further noted that (i) grammaticalization results in an increase in contexts where the grammaticalized item is used and (ii) that a grammaticalized item increases in frequency (Wischer, 2000: 357; Heine, 2003: 587; Bybee, 2003a: 147, 2003b: 603, 2006; Traugott, 2011: 28), thus possibly becoming automated as a single processing unit or a chunk (Bybee, 2003b: 603; Bybee and Torres Cacoullos, 2009; Bybee, 2011: 70).

The synchronic behaviour of the lo que se dice configuration, involving a focusing/emphasizer subjunct function as well as a reformulatory connective use, can be taken to point to an early stage of grammaticalization involving a cluster of structural and semantico-pragmatic factors detailed in (i)-(iv) below: ${ }^{17}$

(i) Decategorialization: This term is generally taken to refer to "the set of processes by which a noun or verb loses its morphosyntactic properties in the process of

\footnotetext{
${ }^{17}$ While grammaticalization is generally understood to be a diachronic process and claims about this process should be backed up with historical evidence, I concur with Narro and Heine (2011: 3) and Langacker (2011), inter alios, that it is also possible to analyze grammaticalization from a synchronic viewpoint.
} 
becoming a grammatical element" (cf. Heine et al., 1991). In the case of verbs in particular, decategorialization implies that as they become grammaticalized, they may lose verb-like attributes such as the ability to show variation in tense, aspect, modality and person-number marking (see further Hopper and Traugott, 1993: 105). In this connection, it must be pointed out that grammaticalized instances of lo que se dice are completely fixed with respect to its tense-aspectmarking features, while this is not the case with nongrammaticalized versions of the same string, as shown in (49)(a)-(b), respectively:

(49) (a) Mr John Spencer no era lo que [se \#decia/\#se ha dicho/\#puede decirse/\#podría decirse/\#ha podido decirse] un hombre intachable

'Mr John Spencer was not what was called/has been called/can be called/may be called/has been called an irreproachable man'

(b) (...) en alemán se escribe mit Karacho (pronúnciese la ch como en Bach) para lo que en español coloquial [se dice/se diríalpuede decirse/podría decirse] a todo gas (...)

Grammaticalized instances of lo que se dice are also frozen with respect to number in contrast to nongrammaticalized instances of, lo que se considera, as illustrated in (50) (a)-(b). In addition, the XPCOMP in this configuration cannot enter in competition with a finite que-clause, as shown in $(50)(\mathrm{c})$ :

(50) (a) La "lambada" llega a su clímax cuando sus protagonistas tienen sangre latina en sus venas y sus cuerpos son lo que se dice/*los que se dicen pura fibra elástica

'The lambada comes to a climax when the participants have Latin blood in their veins and their bodies are what you (would/might) call pure elastic fibre'

(CREA Corpus, 1989, ABC, 02/09/1989: La "lambada" ya está aquí)

(b) Los ejercicios que se hacen cuando está echado sobre la espalda y en los que, por tanto, se apoya sobre el suelo, son los que se consideran, generalmente, más seguros para la espalda books.google.es/books?isbn $=844141651$

'The exercises which are done when one is lying on one's back and in which you leaning on the floor are those which are generally considered to be the safest for your back'

(c) *Mr John Spencer no era lo que se dice (que) es un hombre intachable

Moreover, the fact that the form dice ('say') still preserves some of its verbal traits and is also etymologically transparent to most native speakers, can also be taken to support the claim that this configuration lies at one of the intermediate points in a decategorialization cline (see further ibid.). Furthermore, it has also been noted that the lexical items that grammaticalize are typically what are known as "basic words" (Hopper and Traugott, 1993: 97), which fits in nicely with the general, basic nature of decir ('say') in Spanish, especially in relation to the other verba cogitandi reproduced in Table 7 (see also Davies, 2006: 12 inter alios for further evidence).

Crucially for our purposes here, decategorialization is related to what Bybee and Torres Cacoullos (2009: 189) call "loss of analyzability" and Company Company (2004: 22, 2006: 381) labels "the cancellation of syntax" (Company Company, 2004: 22; 2006: 381). It is again particularly illuminating to consider the acceptability contrasts between grammaticalized instances of lo que se dice with non-grammaticalized versions of the same string in relation to (i) the possibility of inserting any material within the string, (ii) the feasibility of turning this string into the active voice and (iii) the feasibility of coordinating se dice with another verbum dicendi in the passive, as shown in (51)-(52), respectively:

(51) (a) $\mathrm{Mr}$ John Spencer no era lo que (\#comúnmente) se dice (\#comúnmente) un hombre intachable

'Mr John Spencer was not what one may generally call an irreproachable man'

(b) \#Mr John Spencer no era lo que uno dice un hombre intachable

'Mr John Spencer was not what one may call an irreproachable man'

(c) \#Mr John Spencer no era lo que se dice o se llama un hombre intachable

'Mr John Spencer was not what one may call or consider an irreproachable man'

(52) (a) (...) en alemán se escribe mit Karacho (pronúnciese la ch como en Bach) para lo que [comúnmente] en español coloquial [comúnmente] se dice [comúnmente] a todo gas (...)

'In German one writes mit Karacho (you should pronounce the "ch" as in Bach) for what in colloquial Spanish would be normally described as a todo gas'

(b) (...) en alemán se escribe mit Karacho (pronúnciese la ch como en Bach) para lo que en español coloquial uno dice a todo gas (...)

'In German one writes mit Karacho (you should pronounce the "ch" as in Bach) for what in colloquial Spanish one would normally describe as a todo gas' 
(c) (...) en alemán se escribe mit Karacho (pronúnciese la ch como en Bach) para para lo que en español coloquial se dice o se llama a todo $\operatorname{gas}(\ldots)$

(ii) Generalization of meaning: This term designates "the loss of specific features of meaning with the consequent expansion of appropriate contexts of use for a grammar" (Bybee et al., 1994: 289; Lehmann, 1995; Bybee, 2003b: 605) usually through a process of habituation conditioned by repetition. Moreover, in the process of grammaticalization, meanings expand their range through the development of various polysemies (Hopper and Traugott, 1993: 100). In other words, the meaning generalizes in the sense that more and more domains (i.e., polysemies) progressively become available. In the case of the lo que se dice string under scrutiny here, these polysemies involve: (i) a restrictive focusing/emphasizer subjunct (roughly similar to realmente/verdaderamente 'really') and (ii) a summative conjunct (similar to en definitiva 'in short'). In particular, when these polysemies are balanced against the original processual meaning of the lo que se dice string, it can be seen that they involve a shift, rather than a loss, of meaning, thus possibly pointing to an early stage of grammaticalization (see further Hopper and Traugott, 1993: 89, inter alios). Furthermore, as noted by Bybee (2003b: 605), this generalization of meaning appears to pervade the whole grammaticalization continuum, with grammaticalizing items becoming increasingly more general as the process unfolds. This observation ties in well with the fact that the focusing/emphasizer subjunct is less general and/or abstract than the chronologically later connective counterpart (see Gonzálvez-García, 2006 for further discussion of the diachrony of this construction).

(iii) Increase in pragmatic function/pragmatic strengthening: The string in question acquires pragmatic meanings (i.e., a reinforcing emphasizer/focusing subjunct meaning as well as a summative reformulatory connective meaning) but only at the expense of a weakening of part of its original meaning (cf. Traugott, 1988; 1995a; 1995b). Furthermore, the string appears to move along a cline (or, alternatively, a path) of referential $>$ non-referential functions (see further Dasher, 1995). In particular, the synchronic behaviour of the string can be seen to be motivated in terms of a "unidirectional movement away from (its) original specific and concrete reference and toward increasingly general and abstract reference" (Pagliuca, 1994: ix), as detailed below (see further Traugott, 1995b: 14):

concrete action (i.e., a process of sayingevaluation) > evidential/epistemic element (i.e., a (focusing/emphasizer) subjunct) > metatextual elaborator (i.e., a summative reformulatory conjunct)

(iv) Subjectification: The lo que se dice XРCOMP configuration becomes increasingly more associated (in both its (emphasizer/focusing) subjunct and reformulatory summative conjunct functions) with speaker's attitude in general and evaluation in particular regarding the content of the proposition, which is especially evident in the choice of evaluative predicative adjectives and predicate nominals in the XPCOMP slot, as will be argued in some detail in 4.3. However, the summative reformulatory conjunct uses of the configuration in question are even more subjective than their subjunct counterparts, on the grounds that these signal the speaker's attitude to elements in the discourse flow.

Following Traugott (1995b: 15) and Company Company (2008: 205-206), the lo que se dice XPCOMP configuration can be said to instantiate the following two subtypes of grammaticalization:

Subtype I: Syntax via pragmatic strengthening in discourse $\rightarrow$ syntax with a different function.

This grammaticalization type involves the recruitment of already extant grammatical structures at the level of grammar and the development of new polysemies/functions at the grammar level, too, a focusing/emphasizer subjunct function (see Traugott, 2003: 631; Company Company, 2008: 205), as in (47) above:

\section{Subtype II: proposition $\rightarrow$ text $\rightarrow$ discourse}

This involves the development of textual or discourse markers and, unlike subtype I, it operates on the textual or discourse level, thus taking discourse to be the final stage in the process of grammaticalization. More specifically, the nominal relative clause in this case, after cancelling its original syntactic and morphological properties, behaves as an autonomous form which works as a discourse marker or, more exactly, as a reformulatory conjunct (see further Traugott, 1982: 256; Company Company, 2008: 206, inter alios), as in (48) above.

It is our contention that these two subtypes of grammaticalization give rise to two closely connected (and least partially overlapping) constructions in presentday Spanish. In these two constructions the lo que se dice string is completely fixed. Since the words in this string are often produced together, they are also more likely to be stored and processed together (Boyland, 1996; Ellis, 1996), thus qualifying as a chunk (Bybee, 2011: 70). In these two constructions, the lo que se dice string is a grammatical expression in the sense of Boye and Harder (2011). In other words, the string in 
question conveys secondary or backgrounded information (cf. Talmy, 2000) and cannot under normal circumstances be used to convey the main point of a linguistic message (Boye and Harder, 2011: 60), as shown in (53)-(54) for (47)-(48), respectively:

(53) A. Mr John Spencer no era lo que se dice un hombre intachable

B. ¿Qué?

A. \# lo que se dice

A. Un hombre intachable

(54) A. Lo que se dice un ídolo

B. ¿Qué?

A. \# lo que se dice

A. Un ídolo

The lo que se dice string cannot under normal circumstances be brought into focus or addressed in subsequent communication. Thus, a pronunciation of $l o$ que se dice with focal stress in (45)-(46) is highly unusual and the question qué ('what') in (53)-(54) can hardly be interpreted as addressing (or eliciting) the lo que se dice string, but rather the material in the XPCOMP element.

Finally, it should be pointed out that the more holistic processing of the lo que se dice chunk leads to the assignment of focusing/emphasizer subjunct and summative conjunct functions to the whole unit, downgranding the semantico-pragmatic contribution from the components. In other words, the focusing/emphasizer meaning (i.e., realmentel verdaderamente) and the summative conjunct meaning (i.e., o sea/en definitiva) cannot be assembled by accessing the meaning of the individual components of the constructions, which means that these are noncompositional. These two constructions are examined at a higher level of granularity in the next two sub-sections.

\section{The lo que se dice XPCOMP Construction as a Focusing/Emphasizer Subjunct}

For current purposes, the most outstanding properties of the lo que se dice string as a restrictive focusing and/or emphasizer subjunct can be summarized as in (i)-(iv) below:

(i) Configurations of this type can draw attention to a part of a sentence as wide as the predication or as narrow as a single constituent of an element (such as a postmodifying qualifier in a noun phrase as subject complement, or an auxiliary within a verb phrase, as in (55)-(56)) (Quirk, 1985: 604):

(55) Ésta ha sido una faena lo que se dice de altura (scope: postmodifier within an NP)

'This has been a performance that you might call worthy of the occasion'
(CREA Corpus, 1975, Gabriel García-Badell, Funeral por Francia)

(56) (...) Y aquella noche iba lo que se dice corriendo, urgido por algo (...)

(scope: lexical verb within a progressive VP)

'(...) and that night I was, you might say, running off, driven (on) by something'

(CREA Corpus, 1995, Luciano G. Egido, Corazón)

(ii) In much the same way as some focusing subjuncts in English (e.g., only, just), the configuration under examination here may occur either before or after the element it brings into focus. Consider, by way of illustration, (57) below, where the configuration in question occurs as a postmodifier:

(57) (...) ¡venga venga aqui! Usted tendrá más fuerza pero le falta maña no tiene [buena mano lo que se dice] (...)

(...) 'come, come here! You may be stronger but you are not skillful, you don't have what you (would) call a knack' (...)

(CREA Corpus, 1975, Gabriel García-Badell, Funeral por Francia)

(iii) There is an extraordinary degree of morphosyntactic flexibility with regard to the category of the element filling in the postverbal XPCOMP slot. In addition to NPs with an overwhelmingly subjective flavour, as in (47), this string can also felicitously combine with a wide spectrum of morphosyntactic categories, ranging from personal pronouns (58), to prepositional phrases with a literal, locative meaning (59), adverbs (60), infinitives with a dynamic meaning (61), gerunds with a dynamic interpretation (62) and even non-finite clauses with an intervening nominal as subject (63), which do not lend themselves to a subjective (i.e., evaluative) construal or interpretation:

(58) (...) él, lo que se dice él, estaba permanentemente a otras

(CREA Corpus, 1995, Sánchez-Ostiz, Miguel, Un infierno en el jardín

'He, HE, was permanently into something else'

(59) En casa lo que se dice en casa, se quedaron 2 de esos 4 millones que perdió el PSOE

http://eskup.elpais.com/1371154769-

b3e7b3f9db527e9e6bae7b8bda9ce7c8

'Two of the four millions of voters that the PSOE lost stayed at home, home'

(60) Que España va bien, lo que se dice bien, pero que muy bien, es cosa sabida (...)

'That Spain is doing well, what you (would) call well, indeed really well, is something well-known' 
(CREA Corpus, 1997, Época, 08/12/1997: Retrocesos de la España de Aznar)

(61) Dormir, lo que se dice dormir... nadie duerme una hora seguida

(CREA, 1995, PRENSA, El Mundo, 01/06/1995: FUTBOL. LIGA ESPAÑOLA. Previa del encuentro Real Madrid-Deportivo de La Coruña)

'As for what you may call sleeping, no-one sleeps for a full hour'

(62) Claro que caérsele la baba, lo que se dice caérsele la baba a Mary, con la foto de tío Ramón en bañador, una foto donde se veía clarísimo que tío Ramón tenía una facha estupenda

'But drooling, Mary what you (would) call her drooling over the picture of her uncle Ramón in swimming trunks, a picture where it was really evident that uncle Ramón was incredibly goodlooking'

(CREA Corpus, 1991, Eduardo Mendicutti, El palomo cojo)

Crucially, the examples reproduced in (58)-(62) above can be taken to evidence a dramatic increase in the syntactic scope of the grammaticalized lo que se dice string, as shown among other things by the fact that none of the XPCOMPs reproduced in (58)-(62) is acceptable in the higher level constructions outlined in the preceding sections.

(iv) From a semantico-pragmatic viewpoint, the contribution of the lo que se dice XPCOMP construction in question is to focus the denotation of the element in the XPCOMP slot as a prototypical (or 'real') instance, usually with a contrastive focus, as shown by their feasibility of being replaced with realmente and verdaderamente ('really') in Spanish.

(63) Bailar, (realmente) lo que se dice bailar, Pedro Osinaga no lo demuestra en el escenario (más bien mueve su cuerpo ligeramente al son de la música) ${ }^{18}$

'Dancing, really dancing, Pedro Osinaga never does any on the stage [rather, he gently moves his body to the rhythm of the music]'

(CREA Corpus, 1987, ABC, 13/11/1987: Pedro Osinaga: "Nuestra única subvención es la sonrisa del público")

More specifically, these configurations are very similar to instances of contrastive reduplication (Ghomeshi et al., 2004; see also Felíu Arquiola, 2011 and references therein). Interestingly, these configurations qualify as a

\footnotetext{
${ }^{18}$ The material in brackets has been added for the sake of clearer argumentation.
}

case of a discourse-based reduplication in the sense of Suñer Gratacós and Roca (1997-1998: 44-46). By way of illustration, consider (64):

(64) Como Sebas no está loco, lo que se dice loco, loco de atar, pues se dió cuenta de que aquello no era normal (...)

'Since Sebas is not mad, not really mad, what you (would) call mad, stark raving mad, he therefore realized that was not normal'

(CREA Corpus, 1988, Manuel Hidalgo, Azucena, que juega al tenis)

The reduplication of the XPCOMP illustrated in (64) does not involve the creation of new lexical items; the XPCOMP in question may be repeated more than twice, may involve morphosyntactically complex elements (e.g. a complex adjectival phrase such as loco de atar) and need to be separated by pauses in speech and commas in writing (cf. also (65)). Interestingly enough, configurations of this type very frequently $(30 \%$ of the cases) involve left dislocation of the XPCOMP (see further Valenzuela et al., 2005), as in (65) below, a feature often associated with a colloquial style in Spanish (cf. Vigara Tauste, 1992: 144-163):

(65) Pero vamos, enfermo, enfermo, lo que se dice enfermo, pues no [más bien algo debilitado] ${ }^{19}$

'But, sick, sick, what you (would/might) call sick, I don't think he is [but rather a bit weak]'

(CREA Corpus, 1992, Santiago Moncada, Caprichos)

Therefore, an interesting corollary that can be drawn from the preceding discussion is that the distribution as well as the versatility of the XPCOMP element must be understood in terms of an interaction of morphosyntactic, syntactic and lexical factors. Moreover, the versatility of the XPCOMP element and the fixedness of the preceding lo que se dice configuration can be adequately captured by positing a lower-level, partially filled in construction, viz. the lo que se dice XPCOMP within the Impersonal-Subjective Transitive construction in Spanish. In turn, the evidence presented so far can be seen as lending further credence to the notion of construction articulated by Bybee, Thompson and colleagues (see e.g., Bybee and Hopper, 2001) as conventionalized recurring sequences of morphemes or words with open slots (i.e., some positions that allow choices among classes of items of varying size - in this case the XPCOMP slot; cf. Bybee 2003a; 2006; inter alios). Furthermore, the considerable degree of frequency and entrenchment exhibited by this

\footnotetext{
19 The material in brackets has been added for the sake of clearer argumentation.
} 
configuration argues the case for the need to recognize it as a construction in its own right even if some (though not all) of its grammatical and semantico-pragmatic properties can be predicted from the corresponding higher level construction (cf. Goldberg, 2006: 214-215). I will have more to say about this at the end of the next section, when I compare the type of XPCOMPs which can occur in the lo que se dice focusing/emphasizer subjunct construction with those which are felicitous in the lo que se dice summative conjunct construction.

\section{The lo que se dice XPCOMP Construction as a Connective Discourse Marker}

This section examines grammaticalized instances of the lo que se dice string functioning as a discourse marker (see further Schiffrin, 1987; Fraser, 1990) or, more precisely, a conjunct (Quirk, 1985: 631-647; Portolés Lázaro, 1993; Fuentes, 1993; Martín Zorraquino and Portolés Lázaro, 1999: 4055-4056, inter alios), which has the function of "conjoining independent units rather than one of contributing another facet of information to a single integrated unit" (Quirk, 1985: 631), as illustrated in (66) below:

(66) La cantante Alaska (abajo) no sólo canta que su novio es un zombi, sino que también visita todas las salas cinematográficas que proyectan historias para no dormir. Lo que se dice un amor de película

'The singer Alaska (below) not only sings that her boyfriend is a zombie, but also visits all the theatres playing horror movies. In short, a fascinating love'

(CREA Corpus, 1989, ABC, 25/07/1989: La vía láctea).

The scope of modification of the lo que se dice configuration in its function as a conjunct may go all the way from phrasal elements functioning as single phrasal constituents (as in (67)) to, crucially, sentences, paragraphs, or even larger parts of a text (cf. Martín Zorraquino and Portolés Lázaro, 1999: 4070), as in (66):

(67) Después existía un segundo deber consistente en soltar el agua al final de cada servicio, que usted sólo ha hecho aguas menores, lo que se dice un meado normal?

'Then there was a second duty consisting in releasing the water at the end of every service, so you have just peed, what you may call an ordinary pee?'

(CREA Corpus, 1975, Gabriel García-Badell, Funeral por Francia)

In this connection, it is important to note that the conjunct use of the lo que se dice XPCOMP construction is evaluative in at least two significant respects. First, the XPCOMPs which felicitously occur in this construction are normally characterizing NPs with a decidedly evaluative tone (cf. (66)-(67)), thus conveying covert subjectivity (Scheibman, 2002: 158, 169). Second, as Traugott (1995b: 6) aptly reminds us: "What D[iscourse] $\mathrm{M}$ [arker]s do is allow speakers to display their evaluation not of the content of what is said, but of the way it is put together, in other words, they do metatextual work."

The lo que se dice string, when used as a conjunct, must occur in initial position of an utterance (Schiffrin, 1987: 328), as shown in (68):

\section{(68) (a) \#Un amor de película lo que se dice (b) \#Un ídolo lo que se dice}

Crucially, by virtue of their inherent connective function, conjuncts unambiguously display a coherencebuilding potential. This textual dimension is evidenced among other things in the fact that these very often summarize the preceding discourse. In fact, all 28 tokens of the conjunct use of the configuration under examination here perform a summative (Quirk, 1985: 634) or reformulatory (Fuentes, 1993; Portolés Lázaro, 1993; Martín Zorraquino and Portolés Lázaro, 1999: 4072-4073) function. In keeping with such a summative value, they are invariably placed in initial position in the sentence/clause that wraps up the preceding discourse (see further example (67) above). Interestingly enough, this summative value is also physically reflected in a dramatic condensation of the preceding discourse into the XPCOMP element following the lo que se dice string (cf. also Kovacci, 1999: 767). Specifically, the most productive strategy is to encapsulate the preceding stretch of discourse in a relatively short NP (24 out of the 28 tokens; $85.71 \%$ ), as in example (67) above, or in an equally succinct infinitival clause (4 out of the 28 tokens; $14.28 \%$ ), as in (69) below:

(69) De todas maneras, mis hijos tuvieron más suerte que yo. Cuando yo nací, el mío estaba de cuerpo presente. Lo que se dice ni conocerlo

'Anyway, my children were luckier than myself. When I was born, my father was dead, waiting to be buried. In other words, I didn't even get to know him'

(CREA Corpus, 1986, Miguel Delibes, La hoja roja)

Furthermore, a two-fold distinction can be made between paraphrastic reformulatory conjuncts/markers and non-paraphrastic reformulatory ones (cf. Fuentes, 1993; Portolés Lázaro, 1993; Martín Zorraquino and Portolés Lázaro, 1999: 4133). This distinction is motivated by the nature of the recapitulation introduced by the lo que se dice string. In the former type, as in 
example (67) above, the recapitulation does not involve any kind of variation in semantico-pragmatic import and is basically of a semantic type, as shown crucially by e.g., the near-synonymy relationship holding between the NPs aguas menores ('pee' or, alternatively, 'do number one' in British English) and un meado normal ('an ordinary pee'). In the latter type, by contrast, the basis for the recapitulation in question is pragmatic in nature and the material encoded in the XPCOMP after lo que se dice is not just a mere reformulation of the preceding discourse elements. This is the case in example (66), where the NP un amor de película ('a fascinating love') further adds, through a pun, an overwhelming laudatory appraisal by the subject/writer of Alaska's compelling passion for (horror) movies. Interestingly enough, nonparaphrastic reformulatory uses of lo que se dice rank higher in frequency ( 25 tokens out of $28 ; 89.28 \%$ ) in comparison to paraphrastic ones ( 3 out of $28 ; 10.71 \%$ ). ${ }^{20}$

As in the case of the Subjective-Transitive construction and the emphasizer/focusing use of the $l o$ que se dice XPCOMP configuration, the notion of subjectivity can be seen to play a role here. In particular, covert subjectivity (cf. Scheibman, 2002: 158, 169) is encoded through the choice of predicate nominals in the XPCOMP slot conveying a value judgement on the part of the subject/speaker, as illustrated in (67) above. In addition, it must also be borne in mind that the lo que se dice string, by virtue of its conjunct or textual elaborator status is considered to be subjective in itself, insofar as it expresses the speaker's attitude towards some element in the discourse flow (cf. Quirk, 1985: 632; Traugott, 1995a: 40, inter alios). However, an important asymmetry between the summative conjunct lo que se dice configuration and its focusing/emphasizer subjunct counterpart concerns the fact that the conjunct configuration lacks the morphosyntactic flexibility of the focusing/emphasizer subjunct, as shown by the unfelicitous result (at best) of personal pronouns, prepositional phrases with a literal (locative) meaning, adverbs, dynamic infinitives and gerunds and non-finite clauses with an intervening nominal in the XPCOMP slot of the summative conjunct construction:

(70) Lo que se dice un amor de película/\#él/\#en casa/\#bien/\#dormir/\#corriendo/\#cáersele la baba a Mary con la foto de tío Ramón en bañador

\footnotetext{
${ }^{20}$ Searches in Google reveal that uses of the lo que se dice XPCOMP construction as a summative conjunct are gaining momentum and are particularly frequent as headlines or titles for short articles in newspapers, blogs, etc. Typical examples include the following: Lo que se dice un partidazo ('Definitely a good catch!') (used as headline in an article talking about Liliane Bettencourt being the richest woman in Europe) (http://www.diariovasco.com/20080828/ultima/dice-partidazo20080828.html).
}

Table 8. Frequencies of the lo que se dice XPCOMP construction in the CREA Corpus (listed in descending order of frequency)

\begin{tabular}{lcr}
\hline & Tokens & Rate \% \\
\hline Emphasizer/Focusing & 178 & 86.40 \\
subjunct & & \\
Summative conjunct & 28 & 13.59 \\
TOTAL & 206 & 100.00 \\
\hline
\end{tabular}

Table 9. An overview of the behaviour of the lo que se dice XPCOMP constructions

\begin{tabular}{lll}
\hline & $\begin{array}{l}\text { Emphasizer/ } \\
\text { Focusing subjunct }\end{array}$ & $\begin{array}{l}\text { Summative } \\
\text { conjunct }\end{array}$ \\
\hline $\begin{array}{l}\text { Scope } \\
\text { Syntactic position } \\
\text { Type of meaning }\end{array}$ & $\begin{array}{l}\text { Clause/Phrase } \\
\text { Variable Fixed }\end{array}$ & Stretch of discourse \\
Propositional & Metatextual \\
\hline
\end{tabular}

Bearing in mind that the analysis of discourse markers may, in some cases, resist a clear-cut classification, especially in view of the fact that “... any one marker may have a wide variety of meanings which overlap with the meanings of other markers" (Brinton, 1990: 48), it is convenient to highlight at least one example where the lo que se dice string as a focusing/emphasizer subjunct is practically indistinguishable from its connective summative use. In fact, more than $75 \%$ of the native informants agreed that the string reproduced in (71) could be felicitously paraphrased as realmente/ciertamente ('really', 'truly') and en definitiva/o sea ('in short', 'that is'). Interestingly enough, this example builds on the evidence reported in e.g., Schwenter (1996: 870) that Spanish o sea ('that is') manifests properties of both epistemic markers and commentary pragmatic markers, while also lending further credence to Traugott's contention that grammaticalization is gradual (Traugott, 2003: 626) and that the coexistence, or layering, of original and emergent functions is a common function of the grammaticalization of lexical items, at least in its early stages (Hopper and Traugott, 2003: 124-126).

(71) Ahora ya sí que no entiendo nada-cabeceó el maestro con gesto serio-. Lo que se dice nada 'Now I do not really understand anything -nodded the teacher with a serious gesture. Anything at all' (CREA Corpus, 1984, Ramón Ayerra, La lucha inútil)

The distribution of the lo que so dice XPCOMP construction is reproduced in Table 8 , while Table 9 summarizes the main distinctive features of these two constructions in present-day Spanish.

The main bulk of this paper has been concerned with showing that a constructionist analysis is particularly illuminating to capture in its full richness the interaction of lexical semantics and constructional semantics within the family of subjective-transitive constructions with special focus on decir ('say'). More specifically, the use of a default or partial 
inheritance system of the kind invoked in CCG (and other usage-based versions of $\mathrm{CxG}$ ) makes it possible to capture the commonalities between the lower-level configurations of the subjective-transitive construction analyzed here and its higher-level configurations, while also accommodating the idiosyncratic particulars of specific lower-level configurations. This is particularly useful to account for the fact that the lo que se dice XPCOMP focusing/emphasizer subjunct construction also selects as XPCOMP identifying expressions, prepositional phrases with a literal, locative meaning, dynamic infinitives and gerunds, adverbial phrases, etc., systematically disallowed in the lo que se dice XPCOMP summative conjunct construction and the other instances of the subjective-transitive construction scrutinized in this paper (cf. (70)). Moreover, default inheritance, as Gisborne and Patten (2011: 95) rightly observe, is particularly fit for modelling the types of categorization envisaged in Cognitive Semantics and usage-based models, which relies on prototypes and extensions from the prototypes rather than on sufficient and necessary conditions.

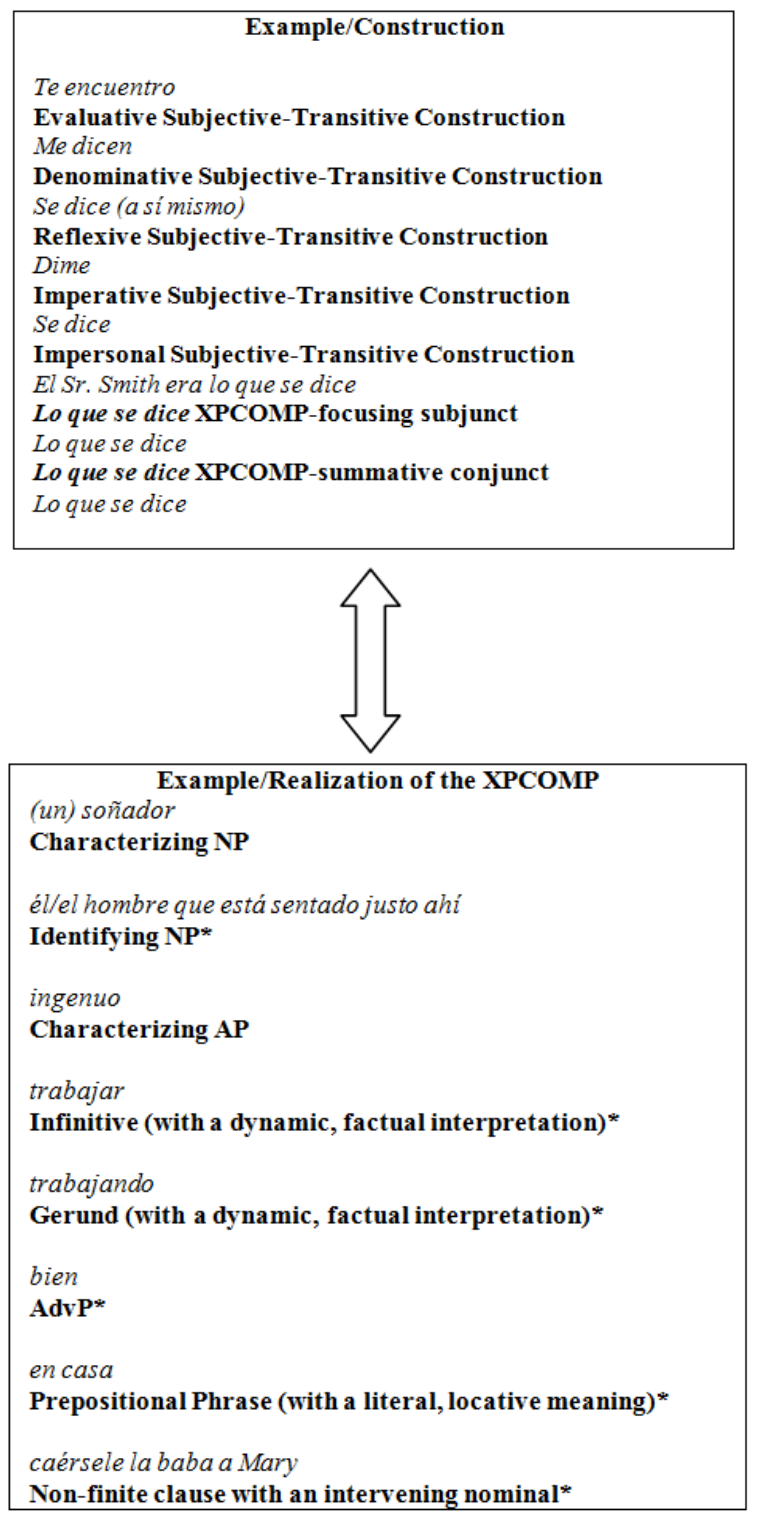

Fig. 4. Generalizations on the semantico-pragmatic profile of the XPCOMP within the family of subjective-transitive constructions in Spanish. ${ }^{21}$

\footnotetext{
${ }^{21}$ The asterisks next to the specific realizations of the XPCOMP listed on the lower box in Figure 4 are meant to reflect informally the fact that these realizations are only felicitous in the lower-level lo que se dice XPCOMP construction functioning as an emphasizer/ focusing subjunct and are not shared by the other instances of the construction scrutinized here, including the lo que se dice XPCOMP construction functioning as a summative conjunct.
} 


\section{Closing Remarks}

In this final section I will pinpoint only briefly a number of aspects in which a cognitively-oriented versions of $\mathrm{CxG}$ can be seen as entering into mutually beneficial relationships with studies advocating a wide view of phraseology in general (see Granger, 2011 and references therein) and Phraseodidactics in particular (González Rey, 2004; 2012; Timofeeva, 2013, inter alios).

First, construction grammar dispenses with a strict division between grammar and the lexicon and submits that grammar, the core as well as the periphery, boils down to a network of learned pairings of form (from morphemes, words, idioms, to partially lexically filled and fully general/schematic patterns) and their associated semantic or discourse functions (Goldberg, 2006: 18). Construction Grammar thus envisages a close, dynamic interaction between grammar and the lexicon in which phraseology plays a crucial role in the vertical as well as horizontal organization of the constructicon. Specifically, the constructionist, usage-based analysis of secondary predication with verba dicendi and decir ('say') outlined here shows that, while important differences in productivity and conventionalization exist across and within instances of the subjective-transitive construction, productive and idiosyncratic (and/or novel) configurations should be best seen as a continuum.

Second, secondary predication after verba dicendi displays a number of intricate semantico-pragmatic constraints and is in addition subject to coercion effects in combination with a reflexive pronoun, an imperative verb form and a reflex passive clitic. The constructionist account presented here relies heavily on enhancing the generative power of constructions and is thus intended to maximize the probabilistic knowledge of constructions and their mappings for efficient appropriate use (see Ellis, 2009) in the advanced Spanish L2 class. It does so by showing that the family resemblance that binds together the different configurations surveyed here and the broad-scale generalizations that it affords us at a propositional as well as textual level can serve as explicit input for a pedagogically principled and unified account of how this construction is realistically used for communicative purposes at a vertical level (i.e., in terms of which verba dicendi are eligible for occurrence in a given lower-level configuration) as well as at a horizontal level (i.e., in terms of the co-occurrence of the verb with other construction's components, such as e.g., a reflexive pronoun, an imperative verb form, a reflex passive clitic, or a particular XPCOMP). In the last instance, the constructionist analysis of the family of subjective-transitive constructions with decir ('say') offered here is guided by the assumption that much is gained by providing teaching input for high-frequency words such as decir ('say') in all its richness rather than focusing exclusively on its primary meanings in relatively unconstrained environments such as the transitive construction with an NP or a finite que-clause, as in (72)(a)-(b):

\section{(72) (a) Yo digo una cosa}

'I say one thing'

(b) De hecho, yo digo que nosotros fabricamos muebles, (...)

(CREA, Oral, Televisión, Madrid, 05/07/91 B)

'As a matter of fact, I say that we make pieces of furniture'

Third, the subjective-transitive construction and its lower-level configurations are the result of the superimposition of multiple non-conflicting constructions. Thus, for instance, the family of subjective-constructions outlined here for verba dicendi in general and decir ('say') in particular cannot be properly understood if one fails to take into account the interaction of the subjective-transitive construction with other constructions, such as the reflexive construction, the imperative construction and the reflex passive construction, to mention only a few representative cases. This take on constructions is, in my opinion, particularly well-suited for the teaching of a whole language through its phraseology embodied in Phraseodidactics (González Rey, 2012: 76).

CCG regards synchrony and diachronically as being inextricably connected. Our analysis of the subjectivetransitive family of constructions in Spanish has been shown to provide a uniform account of the semanticopragmatic and discourse-functional properties of configurations even if these have undergone an early process of grammaticalization. But again the subtypes of grammaticalization that we have observed in the case of the lo que se dice XPCOMP construction are also operational in the case of adverbial expressions of lesser morphosyntactic complexity, such as bien ('well') and en realidad ('in actual fact'), which can function as emphasizer subjuncts and (transitional/summative) conjuncts:

(73) (a) París bien vale una misa http://hombrerefranero.blogspot.com.es/2012/05/p aris-bien-vale-una-misa.html

'Paris is well worth a mass'

(b) Bien, como te decía antes, estaba muy ocupado

'So, anyways I was saying that I was actually very busy'

(74) (a) Mr. Spencer no es en realidad amigo mío 'Mr Spencer was not actually my friend'

(b) Nadie le hizo caso a Luis en la reunión. En realidad, su propuesta no tenía ni pies ni cabeza. (Example taken from Martí Sánchez, 2008: 84) 
'Nobody paid any attention to Luis at the meeting. As a matter of fact, his proposal made no sense at all'

CCG assumes that "[c]ognition, consciousness, experience, embodiment, brain, self and human interaction, society, culture and history are all inextricably intertwined in rich, complex and dynamic ways in language, so an understanding of language is incomplete without them." (Ellis, 2008: 5) (see Ellis and Cadierno, 2009 and Ellis, 2013 for further discussion). This comprehensive and highly interdisciplinary conception of language in general and meaning in particular is fully consonant with the also decidedly interdisciplinary view that Phraseodidactics takes on phraseology, incorporating insights from disparate disciplines, such as glotodidactics, contrastive linguistics, psycholinguistics, neurolinguistics, sociolinguistics or pragmatics, with a view to doing full justice to the complexity of the processes leading up to a full phraseological competence.

Last but not least, CCG (like usage-based models in general) takes processing very seriously. Thus, in the case of the family of subjective-transitive constructions with decir ('say'), as with other constructions, (more) empirical research needs to be carried out into the processing and the storage of chunks or multiword units. As Granger (2011: 131) persuasively argues, it is also necessary that language specialists in general and materials designers in particular pay close attention to the findings emerging from these psycholinguistic experiments. This would be an especially important asset in the process of finding the balance between "exploiting the richness of fine-grained corpus-derived descriptions and keeping the learning load at a manageable level" (Granger, 2011: 131), one of the most challenging (and certainly exciting) tasks that pedagogically-minded construction grammarians, advocates of the wide phraseological view as well as practitioners of Phraseodidactics are more likely than not to be facing in the near future.

\section{Acknowledgement}

The author wishes to thank two anonymous reviewers as well as the editor of this issue for helpful comments on an earlier version of this paper. All usual disclaimers apply.

\section{Funding Information}

Financial support from research projects FFI201340517-P and FFI2013-43593-P funded by the Spanish Ministry of Economy and Competitiveness is gratefully acknowledged.

\section{References}

Bencini, G.M.L. and A.E. Goldberg, 2000. The contribution of argument structure constructions to sentence meaning. J. Memory Lang., 43: 640-651. DOI: $10.1006 /$ jmla.2000.2757

Bisang, W., 2011. Grammaticalization and Typology. In: The Oxford Handbook of Grammaticalization, Heine, B. and H. Narrog (Eds.), Oxford University Press, Oxford, ISBN-13: 9780199586783, pp: 105-117.

Boas, H.C., 2010. Contrastive Studies in Construction Grammar. 1st Edn., John Benjamins, Amsterdam, ISBN-10: 9789027204325, pp: 244.

Boas, H.C. and F. Gonzálvez-García, 2014. Romance Perspectives on Construction Grammar. 1st Edn., John Benjamins, Amsterdam, ISBN-13: 9789027204370 , pp: 316.

Boas, H.C. and I.A. Sag, 2012. Sign-Based Construction Grammar. 1st Edn., CSLI, Stanford, ISBN-10: 9781575866284, pp: 391.

Boye, K. and P. Harder, 2011. Grammaticalization and Functional Linguistics. In: Handbook of Grammaticalization, Heine, B. and H. Narrog (Eds.), OUP Oxford, Oxford, ISBN-13: 9780199586783, pp: 56-68.

Boyland, J.T., 1996. Morphosyntactic change in progress: A psycholinguistic approach. Ph.D. Thesis, University of California, Berkeley, United States of America.

Brinton, L.J., 1990. The Development of Discourse Markers in English. In: Historical Linguistics and Philology, Fisiak, J. (Ed.), Walter de Gruyter, Berlin, ISBN-10: 3110122049, pp: 45-71.

Butler, C.S. and F. Gonzálvez-García, 2014. Exploring Functional-Cognitive Space. 1st Edn., John Benjamins, Amsterdam, ISBN-10: 9789027270221, pp: 597.

Bybee, J., 2003a. Cognitive Processes in Grammaticalization. In: The New Psychology of Language: Cognitive and Functional Approaches to Language Structure, Tomasello, M. (Ed.), L. Erlbaum, Mahwah, ISBN-10: 080583429X, pp: 145-167.

Bybee, J., 2003b. Mechanisms of Change in Grammaticalization: The Role of Frequency. In: The Handbook of Historical Linguistics, Joseph, B.D. and R.D. Janda (Eds.), Wiley, Malden, ISBN-10: 1405127473, pp: 602-623.

Bybee, J., 2006. From usage to grammar: The mind's response to repetition. Language, 82: 711-733. DOI: 10.1353/lan.2006.0186

Bybee, J., 2010. Language, Usage and Cognition. 1st Edn., Cambridge University Press, Cambridge, ISBN-10: 9780521616836, pp: 264. 
Bybee, J., 2011. Usage-Based Theory and Grammaticalization. In: The Oxford Handbook of Grammaticalization, Heine, B. and H. Narrog (Eds.), OUP Oxford, Oxford, ISBN-13: 9780199586783 , pp: 69-78.

Bybee, J., 2013. Usage-Based Theory and Exemplar Representation. In: The Oxford Handbook of Construction Grammar, Hoffman, T. and G. Trousdale, (Eds.), OUP USA, Oxford, ISBN-13: 9780195396683, pp: 49-69.

Bybee, J. and P.J. Hopper, 2001. Frequency and the Emergence of Linguistic Structure. John Benjamins, Amsterdam, ISBN-13: 9789027229489, pp: 492.

Bybee, J. and R. Torres Cacoullos, 2009. The Role of Prefabs in Grammaticization. In: Formulaic Language: Distribution and Historical Change, Corrigan, R., E.A. Moravcsik, H. Ouali and K. Wheatley, (Eds.), John Benjamins, Philadelphia, ISBN-13: 9789027229953, pp: 187-218.

Bybee, J., R. Perkins and W. Pagliuca, 1994. The Evolution of Grammar: Tense, Aspect and Modality in the Languages of the World. 1st Edn., University of Chicago Press, Chicago, ISBN-13: 9780226086651, pp: 398.

Chafe, W. and J. Nichols, 1986. Evidentiality: The Linguistic Coding of Epistemology. Ablex Publishing Corporation, Norwood, NJ., ISBN-10: 0893912034 , pp. 346.

Chomsky, N., 1995. The Minimalist Program. 1st Edn., MIT Press, Cambridge, ISBN-13: 9780262032292 , pp: 420 .

Company Company, C., 2004. Gramaticalización por subjetivización como la prescindibilidad de la sintaxis. Nueva Revista de Filología Hispánica, 52: $1-27$.

Company Company, C., 2006. Zero in Syntax, Ten in Pragmatics or Subjectification as Syntactic Cancellation. In: Subjectification: Various Paths to Subjectivity, Athanasiadou, A., C. Canakis and B. Cornillie (Eds.), Walter de Gruyter, Berlin, ISBN-13: 978-3-11-089297-0, pp: 375-398.

Company Company, C., 2008. The directionality of grammaticalization in Spanish. J. Historical Pragmatics, 9: 200-224. DOI: 10.1075/jhp.9.2.03com

Copestake, A., D. Flickinger, C.J. Pollard and I.A. Sag, 2005. Minimal recursion semantics: An introduction. Res. Lang. Comput., 3: 281-332. DOI: $10.1007 /$ s11168-006-6327-9

Croft, W., 2001. Radical Construction Grammar: Syntactic Theory in Typological Perspective. 1st Edn., Oxford University Press, Oxford, ISBN-13: 978-0-19-829954-7, pp: 416.
Croft, W., 2003. Lexical Rules Vs. Constructions: A False Dichotomy. In: Motivation in Language: Studies in Honor of Günter Radden, Cuyckens, H., T. Berg, R. Dirven and Klaus-Uwe Panther, (Eds.), John Benjamins, Amsterdam, ISBN-13: 9781588114266, pp: 49-68.

Croft, W. and A. Cruse, 2004. Cognitive Linguistics. 1st Edn., Cambridge University Press, New York, ISBN-13: 9780521667708, pp: 356.

Dasher, R.B., 1995. Grammaticalization in the system of Japanese predicate honorifics. PhD Thesis, University of Stanford, California, USA.

Davies, M., 2006. A Frequency Dictionary of Spanish: Core Vocabulary for Learners. 6th Edn., Routledge, New York, ISBN-13: 9780415334297, pp: 296.

De Smet, H. and J.C.Verstraete, 2006. Coming to terms with subjectivity. Cognitive Linguistics, 17: 365-392. DOI: 10.1515/COG.2006.011

Demonte, V. and P. Masullo, 1999. La Predicación: Los Complementos Predicativos. In: Gramática Descriptiva de la Lengua Española, Bosque, I. and V. Demonte (Eds.), Librería Tirant lo Blanch, Madrid, ISBN-10: 84-239-7919-9, pp: 2461-2523.

Diessel, H., 2013. Construction Grammar and First Language Acquisition. In: The Oxford Handbook of Construction Grammar, Hoffmann, T. and G. Trousdale, (Eds.), OUP USA, Oxford, ISBN-13: 9780195396683, pp: 347-364.

Diewald, G., 2006. Context types in grammaticalization as constructions. Constructions SV1-9.

Du Bois, J., 1985. Competing Motivations. In: Iconicity in Syntax, Haiman, J. (Ed.), John Benjamins, Amsterdam, ISBN-13: 9780915027316 , pp: 343-366.

Ellis, N., 1996. Sequencing in SLA: Phonological memory, chunking and points of order. Stud. Second Language Acquisition, 18: 91-126. DOI: $10.1017 / \mathrm{S} 0272263100014698$

Ellis, N., 2008. Phraseology: The Periphery and The Heart of Language. In: Phraseology in Foreign Language Learning and Teaching, Meunier, F. and S. Granger (Eds.), John Benjamins, Amsterdam, ISBN-13: 9789027232441, pp: 1-13.

Ellis, N., 2009. Optimizing the Input: Frequency and Sampling in Usage-Based and Form-Focused Learning. In: The Handbook of Language Teaching, Long, M.H. and C. Doughty (Eds.), Wiley, Malden, ISBN-13: 9781444315790, pp: 139-158.

Ellis, N., 2013. Second Language Acquisition. In: The Oxford Handbook of Construction Grammar, Hoffmann, T. and G. Trousdale (Eds.), OUP USA, Oxford, ISBN-13: 9780195396683, pp: 365-378.

Ellis, N. and T. Cadierno, 2009. Constructing a second language: Introduction to the special section. Annual Rev. Cognitive Linguistics, 7: 111-139.

DOI: $10.1075 /$ arcl.7.05ell 
Faltz, L., 1977. Reflexivization: A Study in universal syntax. Ph.D. Theis, University of California at Berkeley, Berkeley, California, USA.

Felíu Arquiola, E., 2011. Las reduplicaciones léxicas nominales en español actual. Verba, 38: 95-126.

Fernández, S., 2007. La Voz Pasiva en Español: Un Análisis Discursivo. 1st Edn., P. Lang, Frankfurt am Main, ISBN-13: 978-3-631-56109-6, pp: 199.

Fernández Lagunilla, M. and E. De Miguel. 2000. Relaciones entre el léxico y la sintaxis: Adverbios de foco y delimitadores aspectuales. Verba, 26: 97-128.

Fernández Ramírez, S., 1987. Gramática Española: El Verbo y la Oración. 1st Edn., Arco Libros, Madrid, ISBN: 84-7635-009-0, pp: 544.

Fillmore, C.F., 1985. Frames and the semantics of understanding. Quaderni di Semantica, 6: 222-254.

Fillmore, C.F., P. Kay and M.C. O'Connor, 1988. Regularity and idiomaticity in grammatical constructions: The case of let alone. Language, 64: 501-538. DOI: $10.2307 / 414531$

Fraser, B., 1990. An approach to discourse markers. J. Pragmatics, 14: 383-395.

DOI: 10.1016/0378-2166(90)90096-V

Fuentes, C., 1991. Adverbios de modalidad. Verba, 18: 275-321.

Fuentes, C., 1993. Conclusivos y reformulativos. Verba, 20: 171-198.

García, E.C., 1975. The Role of Theory in Linguistic Analysis: The Spanish Pronoun System. 1st Edn., North-Holland, Amsterdam, ISBN-10: 0720461804, pp: 522 .

Ghomeshi, J., R. Jackendoff, N. Rosen and K. Russell. 2004. Contrastive focus reduplication in English (The salad-salad paper). Natural Language Linguistic Theory, 22: 307-357. DOI: 10.1023/B:NALA.0000015789.98638.f9

Gisborne, N. and A. Patten. 2011. Construction Grammar and Grammaticalization. In: The Oxford Handbook of Grammaticalization, Narrog, H. and B. Heine (Eds.), OUP Oxford, New York, ISBN-13: 9780199586783, pp: 92-104.

Goldberg, A., 1995. Constructions: A Construction Grammar Approach to Argument Structure. 1st Edn., University of Chicago Press, Chicago, ISBN-10: 0-226-30086-2, pp: 265.

Goldberg, A., 1998. Patterns of Experience in Patterns of Language. In: The New Psychology of Language, Tomasello, M. (Ed.), Lawrence Erlbaum, Mahwah, N.J., ISBN-13: 978-0805834284, pp: 203-219.

Goldberg, A., 2006. Constructions at Work: The Nature of Generalization in Language. 1st Edn., Oxford University Press, Toronto, ISBN-13: 9780199268528 , pp: 280 .
Goldberg, A., 2011. Argument structure constructions: Items and generalizations. Plenary delivered at the $44^{\text {th }}$ Annual Meeting of the Societas Linguistica Europaea, University of La Rioja, Logroño.

Goldberg, A., 2013. Constructionist Approaches. In: The Oxford Handbook of Construction Grammar, Hoffmann, T. and G. Trousdale (Eds.), OUP USA, Oxford, ISBN-13: 9780199586783, pp: 15-31.

González Rey, M.I., 2004. A fraseodidáctica: Un eido da fraseoloxía aplicada. Cadernos Fraseoloxía Galega, 6: 113-130.

González Rey, M.I., 2012. De la didáctica de la fraseología a la fraseodidáctica. Paremia, 21: 67-84.

Gonzálvez-García, F., 2006. Passives without actives: Evidence from verbless complement clauses in Spanish. Constructions SV1-5/2006, 1: 1-65.

Gonzálvez-García, F., 2007. 'Saved by the reflexive': Evidence from coercion via reflexives in verbless complement clauses in English and Spanish. Annual Rev. Cognitive Linguistics, 5: 193-238. DOI: 10.1075/arcl.5.09gon

Gonzálvez-García, F., 2008. The Interaction Between Coercion and Constructional Polysemy: The Case of Verba Dicendi et Declarandi in Secondary Predication in English and Spanish. In: Current Trends in Contrastive Linguistics: Functional and Cognitive Perspectives, González, M.A., J.L. Mackenzie and E.M. González Álvarez, (Eds.), John Benjamins, Amsterdam, ISBN-13: 9789027215710, pp: 281-321.

Gonzálvez-García, F., 2009. The family of object- related depictives in English and Spanish: Towards a usagebased constructionist analysis. Language Sci., 31: 663-723. DOI: 10.1016/j.langsci.2008.01.003

Gonzálvez-García, F., 2011. Metaphor and metonymy do not render coercion superfluous: Evidence from the subjective-transitive construction. Linguistics, 49: 1305-1358. DOI: 10.1515/ling.2011.037

Gonzálvez-García, F., 2014. Words as Constructions: Some Reflections in the Light of Constructionist Approaches. In: To Be or Not to Be a Word: New Reflections on the Definition of Word, IbarretxeAntuñano, I. and J.L. Mendívil-Giró (Eds.), Cambridge Scholars Publishing, Newcastle upon Tyne, ISBN-10: 1-4438-6207-X, pp: 164-188.

Gonzálvez-García, F. and C.S. Butler, 2006. Mapping functional-cognitive space. Annual Rev. Cognitive Linguistics, 4: 39-96. DOI: 10.1075/arcl.4.04gon

Granger, S., 2011. From Phraseology to Pedagogy: Challenges and Prospects. In: The Phraseological View of Language: A Tribute to John Sinclair, Herbst, T., S. Faulhaber and P. Uhrig, (Eds.), Walter de Gruyter, Berlin, ISBN-13: 978-3-11-025701-4, pp: 123-146. 
Gries, S., 2013. Data in Construction Grammar. In: The Oxford Handbook of Construction Grammar, Hoffmann, T. and G. Trousdale, (Eds.), OUP USA, Oxford, ISBN-13: 9780199586783, pp: 93-108.

Haiman, J., 1991. Motivation, Repetition and Emancipation: The Bureaucratization of Language. In: Linguistic Studies Presented to John L. Finlay, Wolfart, H.C. and J.L. Finlay, (Ed.), Algonquian and Iroquoian Linquistics, Winnipeg, ISBN-10: 0-921064-08-X, pp: 45-70.

Halliday, M.A.K., 1985. An Introduction to Functional Grammar. 1st Edn., Edward Arnold Press, Cambridge, ISBN-10: 0713163658, pp: 387.

Heine, B., 2003. Grammaticalization. In: The Handbook of Historical Linguistics, Joseph, B. and R. Janda (Eds.), Wiley, Malden, ISBN-10: 0631195718, pp: 575-601.

Heine, B., U. Claudi and F. Hünnemeyer, 1991. From Cognition to Grammar: Evidence from African Languages. In: Approaches to Grammaticalization, Traugott, E. and B. Heine (Eds.), John Benjamins, Amsterdam, ISBN-13: 9789027228956, pp: 149-187.

Hopper, P.J., 2007. Linguistics and micro-rhetoric a twenty-first century encounter. J. English Linguistics, 35: 236-252. DOI: 10.1177/0075424207305307

Hopper, P.J. and E.C. Traugott, 1993. Grammaticalization. 1st Edn., Cambridge University Press, Cambridge, ISBN-10: 0521804213, pp: 256.

Hopper, P.J. and E.C. Traugott, 2003. Grammaticalization. 2nd Edn., Cambridge University Press, Cambridge, ISBN-10: 0521804213, pp: 276.

Kay, P., 1997. Words and the Grammar of Context. 1st Edn., CSLI Publications, Stanford, ISBN-13: 9781881526179, pp: 263.

Kay, P., 2013. The Limits of (Construction) Grammar. In: The Oxford Handbook of Construction Grammar, Hoffmann, T. and G. Trousdale, (Eds.), O.U.P. USA, Oxford, ISBN-13: 9780199586783 , pp: 32-48.

Kay, P. and C. Fillmore, 1999. Grammatical constructions and linguistic generalizations: The what's X doing Y? construction. Language, 75: 1-33. DOI: 10.1353/lan.1999.0033

Kovacci, O., 1999. El Adverbio. In: Gramática Descriptiva de la Lengua Española, Bosque, I. and V. Demonte, (Eds.), Librería Tirant lo Blanch, Madrid, ISBN-10: 84-239-7918-0, pp: 705-786.

Lakoff, G., 1987. Women, Fire and Dangerous Things: What Categories Reveal about the Mind. 1st Edn., University of Chicago, Chicago, pp: 600.

Langacker, R., 1987. Foundations of Cognitive Grammar: Theoretical Prerequisites. 1st Edn., Stanford University Press, Stanford, ISBN-10: 0804738513, pp: 540.

Langacker, R., 2000. A Dynamic Usage-Based Model. In: Usage-Based Models of Language, Barlow, $\mathrm{M}$. and S. Kemmer, (Eds.), CSLI Publications, Stanford, ISBN-10: 1575862190, pp: 1-63.
Langacker, R., 2005. Integration, Grammaticization and Constructional Meaning. In: Grammatical Constructions: Back to the Roots, Fried, M. and H.C. Boas (Eds.), John Benjamins, Philadelphia, ISBN-10: 9027218242, pp: 157-189.

Langacker, R., 2008. Cognitive Grammar: A Basic Introduction. 1st Edn., Oxford University Press, New York, ISBN-10: 0195331958, pp: 562.

Langacker, R., 2011. Grammaticalization and Cognitive Grammar. In: The Oxford Handbook of Grammaticalization, Heine, B. and H. Narrog (Eds.), O.U.P. Oxford, New York, ISBN-13: 9780199586783, pp: 79-91.

Lehmann, C., 1995. Thoughts on Grammaticalization. 1st Edn., Lincom Europa, München, ISBN-10: 3929075504, pp: 192.

Lehmann, C., 2002. Thoughts on Grammaticalization. 2nd Edn., Seminar für Sprachwiss. der Univ., Erfurt, pp: 171.

Lyons, J., 1982. Deixis and Subjectivity: Loquor, Ergo Sum? In: Speech, Place and Action: Studies of Deixis and Related Topics, Jarvella, R.J. and W. Klein (Eds.), Wiley, New York, ISBN-10: 0471100455, pp: 101-124.

Mairal Usón, R. and F. Gonzálvez-García, 2010. Verbos y Construcciones en el Espacio Cognitivo-Funcional Del Siglo XXI. In: La Gramática del Sentido: Léxico y Sintaxis en la Encrucijada, Val Álvaro, J.F. and M.C. Horno Chéliz, (Eds.), Prensas Universitarias de Zaragoza, Zaragoza, ISBN 10: 8415031505, pp: 123-152.

Maldonado, R., 1999. A Media Voz: Problemas Conceptuales del Clítico Se. Edn., Instituto de Investigaciones Filológicas, UNAM, México, ISBN10: 9683674747 , pp: 480.

Martí Sánchez, M., 2008. La hipótesis de la subjetivización en la pragmaticalización/gramaticalización de los operadores pragmáticos. Paremia, 17: 79-90.

Martín Zorraquino, M.A., 1979. Las Construcciones Pronominales en Español: Paradigma y Desviaciones. Edn., Gredos, Madrid, ISBN-10: 8424907949, pp: 413.

Martín Zorraquino, M.A. and J. Portolés Lázaro, 1999. Los Marcadores del Discurso. In: Gramática Descriptiva de la Lengua Española, Bosque, I. and V. Demonte (Eds.), Librería Tirant lo Blanch, Madrid, ISBN-10: 8423979180, pp: 4051-4213.

Martínez Vázquez, M., 2004. Learning argument structure generalizations in a foreign language. Vigo Int. J. Applied Linguistics, 1: 151-165.

Mendikoetxea, A., 1999. Construcciones Inacusativas y Pasivas. In: Gramática Descriptiva de la Lengua Española, Bosque, I. and V. Demonte (Eds.), Librería Tirant lo Blanch, Madrid, ISBN-10: 8423979180, pp: 1575-1722. 
Michaelis, L.A., 2003. Headless Constructions and Coercion by Construction. In: Mismatch: FormFunction Incongruity and the Architecture of Grammar, Francis, E.J. and L.A. Michaelis (Eds.), CSLI Publications, Stanford, ISBN-10: 1575863839, pp: 259-310.

Michaelis, L.A., 2004. Type shifting in construction grammar: An integrated approach to aspectual coercion. Cognitive Linguistics, 15: 1-67. DOI: $10.1515 / \operatorname{cog} 1.2004 .001$

Michaelis, L.A., 2011. Stative by construction. Linguistics, 49: 1359-1400.

DOI: $10.1515 /$ ling. 2011.038

Narrog, H. and B. Heine, 2011. Introduction. In: The Oxford Handbook of Grammaticalization, Heine, B. and H. Narrog, (Eds.), O.U.P. Oxford, New York, ISBN-13: 9780199586783, pp: 1-16.

Pagliuca, W., 1994. Perspectives on Grammaticalization. 1st Edn., John Benjamins, Amsterdam, ISBN-10: 9027236127, pp: 306.

Portolés Lázaro, J., 1993. La distinción entre los conectores y otros marcadores del discurso en español. Verba, 20: 141-170.

Pustejovsky, J., 1991. The generative lexicon. Comput. Linguistics, 17: 409-441.

Quirk, R., 1985. A Comprehensive Grammar of the English Language. 1st Edn., Longman, London, ISBN-10: 0582517346, pp: 1779.

Suñer Gratacós, A. and F. Roca, 1997-1998. Reduplicación y tipos de cuantificación en español. Estudi General: Revista Facultat Lletres Universitat Girona, 17-18: 37-67.

Ruiz de Mendoza Ibáñez, F.J. and M.S. Peña Cervel. 2008. Grammatical Metonymy within the 'Action' Frame in English and Spanish. In: Current Trends in Contrastive Linguistics: Functional and Cognitive Perspectives, González, M.A., J.L. Mackenzie and E.M. González Álvarez, (Eds.), John Benjamins, Amsterdam, ISBN-10: 9027215715, pp: 251-280.

Sag, I.A., H.C. Boas and P. Kay, 2012. Introducing SignBased Construction Grammar. In: Sign-Based Construction Grammar, Boas, H.C. and I.A. Sag (Eds.), CSLI Publications, Stanford, ISBN-10: 1575866285, pp: 1-29.

Sánchez López, C., 2002. Las Construcciones con 'Se'. Estado de la Cuestión. In: Las Construcciones Con 'Se', Sánchez López, C. (Ed.), Visor Libros, Madrid, ISBN-10: 8475229662, pp: 13-163.

Scheibman, J., 2002. Point of View and Grammar: Structural Patterns of Subjectivity in American English Conversation. John Benjamins, Amsterdam, ISBN-10: 9027226210, pp: 187.

Schiffrin, D., 1987. Discourse Markers. 1st Edn., Cambridge University Press, Cambridge, ISBN: 9780521357180, pp: 376.
Schönefeld, D., 2006. Constructions. Constructions SV1$1 / 2006$.

Schwenter, S.A., 1996. Some reflections on o sea: A discourse marker in Spanish. J. Pragmatics, 25: 855-874. DOI: 10.1016/0378-2166(95)00023-2

Slobin, D.I., 1985. The Crosslinguistic Study of Language Acquisition. 1st Edn., Lawrence Erlbaum Associates, N.J., ISBN-10: 0898593670, pp: 1332.

Talmy, L., 2000 (2003). Toward a Cognitive Semantics. 1st Edn., MIT Press, Cambridge, ISBN-10: 0262700980, pp: 495.

Taylor, J., 2003. Cognitive Grammar. 1st Edn., Oxford University Press, Oxford, ISBN-10: 0198700334, pp: 640 .

Timofeeva, L., 2013. Fraseodidáctica: A fraseoloxía para a didáctica. Cadernos Fraseoloxía Galega, 15: 393-410.

Tomasello, M., 1998. Introduction: A CognitiveFunctional Perspective on Language Structure. In: The New Psychology of Language: Cognitive and Functional Approaches to Language Structure, Tomasello, M. (Ed.), Lawrence Erlbaum, Mahwah, NJ, ISBN-10: 0805834281, pp: 9-23.

Traugott, E.C., 1982. From Propositional to Textual and Expressive Meanings: Some Semantic-Pragmatic Aspects of Grammaticalization. In: Perspectives on Historical Linguistics, Winfred P.L. and Y. Malkiel (Eds.), John Benjamins, Amsterdam, ISBN-10: 9027235163, pp: 245-271.

Traugott, E.C., 1988. Pragmatic strengthening and grammaticalization. Ann. Meet. Berkeley Linguist. Society, 14: 406-416. DOI: 10.3765/bls.v14i0.1784

Traugott, E.C. 1995a. Subjectification in Grammaticalisation. In: Subjectivity and Subjectivization: Linguistic Perspectives, Stein, D. and S. Wright, (Eds.), Cambridge University Press, Cambridge, ISBN-10: 9780521023498. pp: 31-54.

Traugott, E.C., 1995b. The role of the development of discourse markers in a theory of grammaticalization. Paper presented at ICHL XII, Manchester.

Traugott, E.C., 2003. Constructions in Grammaticalization. In: The Handbook of Historical Linguistics, Joseph, B.D. and R.D. Janda, (Eds.), Blackwell, Oxford, pp: 624-647.

Traugott, E.C., 2011. Grammaticalization and Mechanisms of Change. In: The Oxford Handbook of Grammaticalization, Heine, B. and H. Narrog (Eds.), O.U.P. Oxford, New York, ISBN-13: 9780199586783, pp: 21-30.

Traugott, E.C. and R.B. Dasher, 2002(2001). Regularity in Semantic Change. 1st Edn., Cambridge University Press, Cambridge, ISBN-10: 1139431153, pp: 341.

Valenzuela, J., J. Hilferty and M. Garachana, 2005. On the reality of constructions: The Spanish reduplicativetopic construction. Annual Rev. Cognitive Linguist., 3: 201-215. DOI: 10.1075/arcl.3.11val 
Valenzuela, J. and A. Rojo. 2008. What Can Language Learners Tell Us about Constructions? In: Cognitive Approaches to Pedagogical Grammar: Volume in Honour of René Dirven, De Knop, S. and T. De Rycker, (Eds.), Walter de Gruyter, Berlin, ISBN-10: 9783110205381, pp: 197-229.

Vera Luján, A., 1996-97. Esquemas oracionales ergativos reflexivos. Estudios Lingüística Universidad Alicante, 11: 385-409.

Vigara Tauste, A., 1992. Morfosintaxis Del Español Coloquial: Esbozo Estilístico. 2nd Edn., Madrid, ISBN-10: 9788424914820, pp: 507.

Wierzbicka, A., 1988. The Semantics of Grammar. 1st Edn., John Benjamins, Amsterdam, ISBN-10: 9789027230195, pp: 617.
Wischer, I., 2000. Grammaticalization Versus Lexicalization. 'Methinks' There Is Some Confusion. In: Pathways of Change: Grammaticalization in English, Fischer, O., A. Rosenbach and D. Stein (Eds.), John Benjamins, Amsterdam, ISBN-10: 9789027230560, pp: 355-370.

Ziegeler, D., 2007. A word of caution on coercion. J. Pragmat., 39: 990-1028.

DOI: $10.1016 /$ j.pragma.2006.07.014

Ziegeler, D., 2010. Count-mass coercion and the perspective of time and variation. Constructions Frames, 2: 33-73. DOI: 10.1075/cf.2.1.02zie 